\title{
14. EARLY TO MIDDLE MIOCENE SEQUENCES, SYSTEMS TRACTS, AND BENTHIC FORAMINIFERAL BIOFACIES, NEW JERSEY COASTAL PLAIN ${ }^{1}$
}

\author{
Kenneth G. Miller, ${ }^{2,3}$ Scott Rufolo, ${ }^{2}$ Peter J. Sugarman, ${ }^{4}$ Stephen F. Pekar, ${ }^{2}$ James V. Browning, ${ }^{2}$ and David W. Gwynn ${ }^{2}$
}

\begin{abstract}
We identified and dated nine lower to middle Miocene sequences at the Island Beach, Atlantic City, and Cape May, New Jersey boreholes, integrating Sr-isotopic, lithofacies, $\log$, and benthic foraminiferal biofacies data in a sequence stratigraphic framework. Miocene sequences typically shallow upsection, representing three major lithofacies: (1) thin, shelly, glauconite sands of the Transgressive Systems Tracts deposited in inner-middle (0- to 100-m paleodepth) neritic environments; (2) medial silty clays of the lower Highstand Systems Tracts deposited in neritic prodelta environments; and (3) upper quartz sands of the upper Highstand Systems Tracts, deposited in inner neritic, near-shore, and delta front environments. Sedimentation rates were low-moderate in the earliest Miocene (5-24 m/m.y.), increased to $40-90 \mathrm{~m} / \mathrm{m} . \mathrm{y}$. at about $22 \mathrm{Ma}$ as deltaic sedimentation began, and remained high and uniform through the middle Miocene. We develop a benthic foraminiferal biofacies model for the inner to middle neritic zones (0- to 100-m paleodepth) and show that these biofacies follow a predictable succession in the se transgressive/regressive sequences. The nomenclature and usage of the Kirkwood Formation is discussed, and the Brigantine Member is formally named.

Onshore sequences result from a complex interplay of changes in eustasy, tectonics, and sediment supply. Correlation of sequence boundaries onshore with offshore and Exxon records indicate that they represent global lowerings of baselevel. Correlation of the sequence boundaries with $\delta^{18} \mathrm{O}$ increases show that they were formed during glacioeustatic lowerings. Although eustasy controls the timing of sequences, the preservation of sequences is also controlled by local tectonic effects while their architecture is strongly influenced by changes in sediment supply and provenance. For example, differences in preservation of sequences is attributed to differential tectonic subsidence due to changes in sediment loading. The depositional patterns onshore allow prediction of offshore sequence architecture, including a progressive progradational change to deltaic sedimentation in the early to middle Miocene; in addition, the absence of lowstand deposits onshore during an interval of high sediment supply may indicate the presence of substantial lowstand systems tracts offshore.
\end{abstract}

\section{INTRODUCTION}

Primary goals of the New Jersey Sea-level Transect were to recover and date Oligocene to Holocene sequences, to compare them to global deep-sea $\delta^{18} \mathrm{O}$ records, and to evaluate sequence stratigraphic models (see Miller, Chapter 1, this volume for summary). It is particularly critical to evaluate the early and middle Miocene, because there are at least eight well-defined $\delta^{18} \mathrm{O}$ increases that reflect glacioeustatic lowerings (Miller et al., 1991, 1996c). In addition, sequences of this age are particularly well developed both onshore and offshore of New Jersey (Miller and Mountain, 1994). Thus, studies of the Miocene onshore strata should allow evaluation of the response of sedimentation to glacioeustatic lowerings (e.g., Miller et al., 1996c; Sugarman et al., Chapter 12, this volume) and the architecture of facies changes within sequences.

Offshore, lower to middle Miocene sequences beneath the modern inner and middle shelf are thick (often hundreds of meters per sequence) and consist of prograding clinoforms that have clear reflector terminations (Greenlee et al., 1992; see "Discussion"). Onshore, the lower to middle Miocene Kirkwood Formation comprises a thick record (up to 216-m total thickness and up to $47 \mathrm{~m}$ per sequence) record of near-shore and shelf (neritic) quartz sands and silty clays influenced by deltaic sedimentation (see Appendix for discussion of Kirkwood Formation nomenclature). Sugarman et al. (1993) recog-

${ }^{1}$ Miller, K.G., and Snyder, S.W. (Eds.), 1997. Proc. ODP, Sci. Results, 150X: College Station, TX (Ocean Drilling Program).

${ }^{2}$ Department of Geological Sciences, Rutgers University, Piscataway, NJ 08855, U.S.A.kgm@ rci-rutgers.edu

${ }^{3}$ Lamont-Doherty Earth Observatory of Columbia University, Palisades, NY 10964, U.S.A.

${ }^{4}$ New Jersey Geological Survey, CN 427, Trenton, NJ 08625, U.S.A. nized five Kirkwood sequences: Kw1a, Kw1b, Kw2a, Kw2b, and $\mathrm{Kw} 3$, from oldest to youngest, and used $\mathrm{Sr}$ isotopes to correlate these sequences to the Berggren et al. (1985) time scale. Because only two continuously cored Miocene sections were available (ACGS\#4 and Belleplain; Fig. 1), their study did not address fully the nature and timing of Miocene sequences. As part of the New Jersey Sea Level Transect, researchers on Leg 150X (a collaboration of Continental Scientific Drilling and the Ocean Drilling Program) drilled three continuously cored boreholes at Island Beach, Atlantic City, and Cape May, NJ (Miller, et al., 1994, 1996a; Fig. 1), which recovered thicker and more complete Miocene sequences than were previously available. Preliminary descriptions of the sequences were provided in the Initial Reports (Miller, et al., 1994, 1996a), where at least nine lower to middle Miocene sequences were recognized: Kw0, Kw1a, Kw1b, $\mathrm{Kw} 1 \mathrm{c}, \mathrm{Kw} 2 \mathrm{a}, \mathrm{Kw} 2 \mathrm{~b}, \mathrm{Kw} 2 \mathrm{c}, \mathrm{Kw} 3$, and Kw-Cohansey (Figs. 2, 3). These sections allow us to date the Miocene sequences and to develop a sequence stratigraphic model for onshore deposition.

Previous studies of the Miocene sequences in these boreholes have addressed either their relationship to the $\delta^{18} \mathrm{O}$ record (Miller and Sugarman, 1995; Miller et al., 1996c; and Sugarman et al., Chapter 12, this volume) or the facies succession at individual sites (Miller, et al., 1994, 1996a; Owens et al., Chapter 2, this volume; Sugarman and Miller, 1997). This study reconstructs lower to middle Miocene sequence stratigraphic architecture by integrating age, lithofacies, well$\log$, and benthic foraminiferal biofacies data at all three Leg 150X sites. We address lower to middle Miocene sequences by providing:

1. detailed (re)evaluation of their ages and estimates of sedimentation rates;

2. lithofacies interpretation of the paleoenvironments represented;

3 . benthic foraminiferal biofacies data that independently constrains interpretations of paleoenvironments; and 


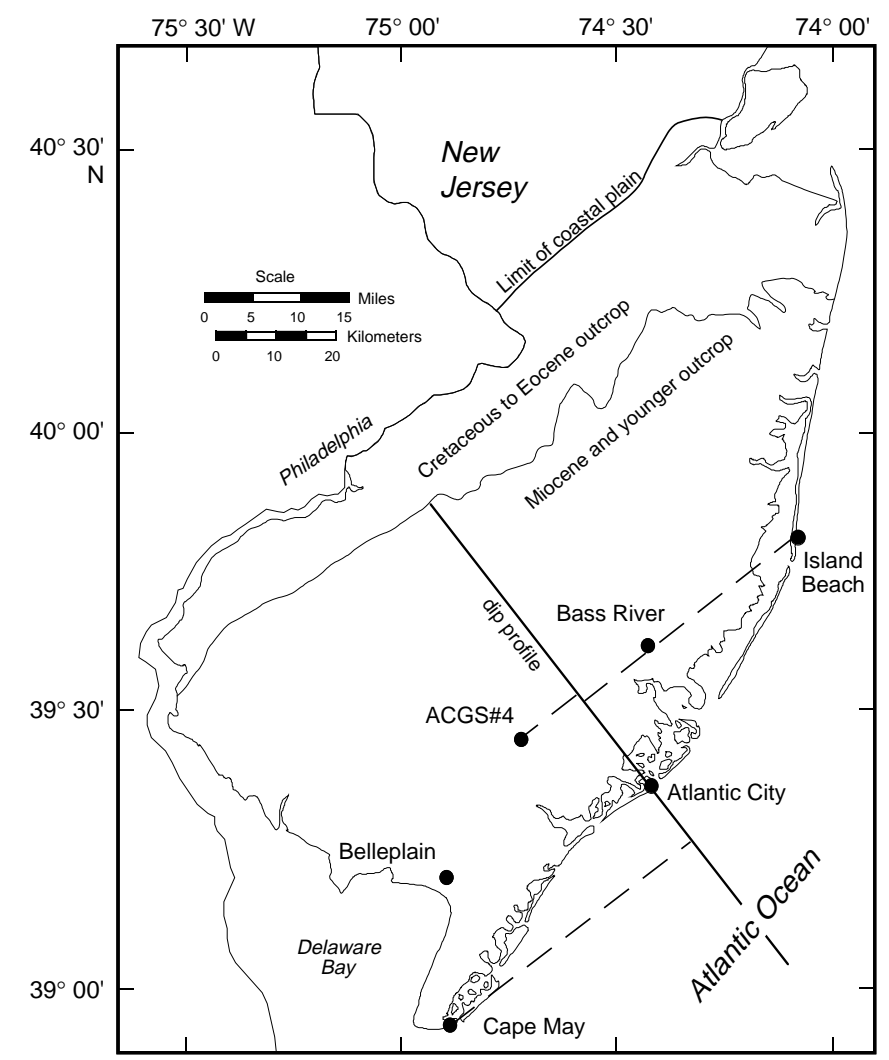

Figure 1. New Jersey location map showing Leg 150X (Island Beach, Atlantic City, and Cape May), Belleplain, and ACGS\#4 boreholes. A dip profile is drawn through Atlantic City and the projections of the Cape May and Island Beach boreholes are shown.

4. integration of the lithofacies, well-log, and biofacies data into systems tracts successions within sequences.

We compare the sequence stratigraphic record of the New Jersey Miocene sequences among the onshore sites to evaluate tectonic effects, and with the global $\delta^{18} \mathrm{O}$ and Exxon (Haq et al., 1987) records to evaluate eustatic controls.

\section{METHODS}

\section{Identification and Characterization of Sequences}

Miocene sequences in the New Jersey Coastal Plain are generally transgressive/regressive siliciclastic sequences consisting of basal clayey sands (transgressive), medial clays and silts, and upper coarse quartz sands (both regressive; Sugarman et al., 1993; fig. 4 in Miller, Chapter 1, this volume). The basal clayey sands often contain glauconite and shell beds in downdip locations. The lower clayey sands correspond to the Transgressive Systems Tract (TST), the clay-silts to the lower Highstand Systems Tract (HST), and the upper quartz sands to the upper HST (Posamentier et al., 1988). Lowstand systems tracts (LSTs) have not been recognized in the coastal plain, and the TSTs are generally thin. Flooding surfaces, particularly maximum flooding surfaces (MFS), are difficult to differentiate from unconformities because of thin TSTs and because both are marked by shell beds. We observe smaller scale parasequences (shoaling-upward cycles bounded by flooding surfaces; sensu Van Wagoner et al., 1988) within several sequences (e.g., within the Kw1b sequence, Figs. 4, 5).

Unconformities in the boreholes were recognized as surfaces with irregular contacts, reworking, bioturbation, and major facies changes

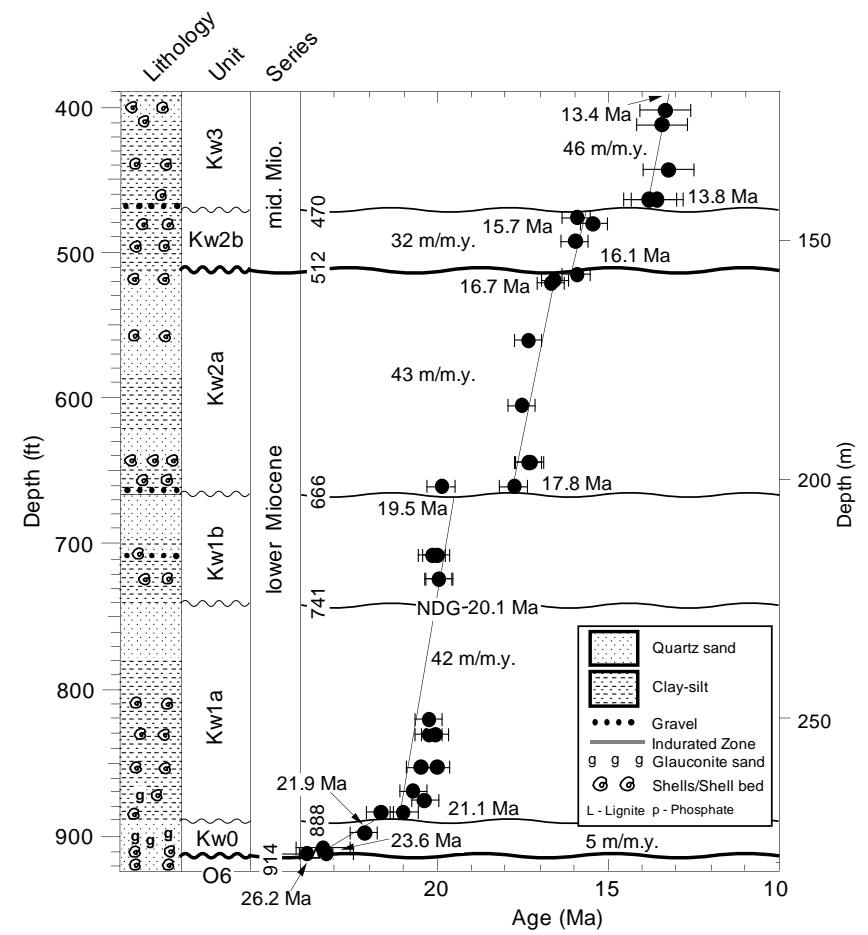

Figure 2. Age-depth diagram, Atlantic City borehole. Solid circles are Sr-isotopic age estimates. Error bars are \pm 0.4 m.y. older than $15.2 \mathrm{Ma}$ and \pm 0.8 m.y. younger than 15.2 Ma. Wavy lines indicate unconformities. NDG $=$ no discernible time gap. Inset shows key for lithological symbols on this and subsequent figures.

(Miller, et al., 1994, 1996a). In addition, many of the unconformities are associated with distinct downhole gamma-ray peaks $(182,303$, and $508 \mathrm{ft}$ at Island beach, Fig. 4; 914, 666, and $512 \mathrm{ft}$ at Atlantic City, Fig. 5). Gamma-ray peaks associated with sequence boundaries are more subdued at Cape May (850 ft, Fig. 6).

Flooding surfaces, particularly MFSs, may be recognized by lithofacies successions and benthic foraminiferal changes. For example, MFSs are often marked by high organic carbon and associated peak abundances of Uvigerina (Loutit et al., 1988), benthic foraminiferal abundance maxima (Pekar et al., Chapter 15, this volume), and changes from deepening-upward to shallowing-upward biofacies successions. Gamma-ray peaks also can be associated with MFSs and condensed sections (Loutit et al., 1988). In the New Jersey Miocene, upsection lithofacies changes from clayey sands to silts often mark the MFS.

It is not always possible to distinguish among unconformities, flooding surfaces, transgressive/ravinement surfaces, and autocyclical facies changes based on lithofacies and well-log interpretations alone. In our study, unconformities that bound major Miocene sequences are associated with hiatuses inferred from Sr-isotopic stratigraphy, whereas MFSs and within-sequence facies shifts are associated with inferred continuous deposition. There is one exception to this rule: the sharp and distinct facies changes, gamma-ray kick, and physical break associated with the $\mathrm{Kw} 1 \mathrm{a} / \mathrm{Kw} 1 \mathrm{~b}$ sequence boundary is within the resolution of Sr-isotopic dating, and there is no discernible hiatus, although the physical and well-log stratigraphy clearly indicates that this is a disconformity.

\section{Biofacies and Logs}

General lithologic descriptions of the Initial Reports (Miller, et al., 1994, 1996a) were supplemented by subsequent studies by 


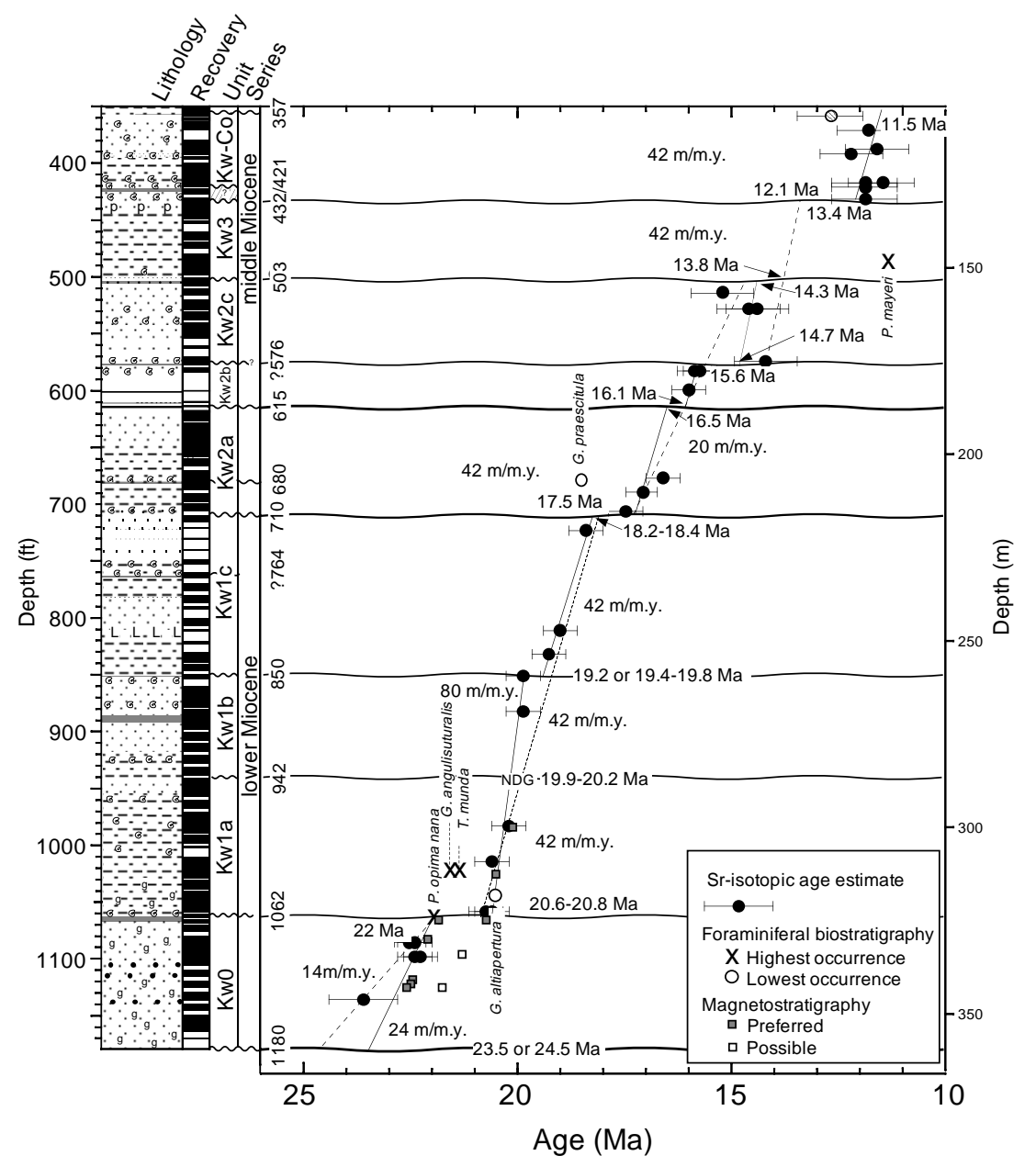

Figure 3. Age-depth diagram, Cape May borehole. Solid lines are drawn for preferred sedimentation rates, dashed lines indicate other possible interpretations. See Figure 2 caption for further explanation. Anomalous age is cross hatched.
Owens et al. (Chapter 2, this volume) for the Island Beach borehole and by Sugarman and Miller (1997) for the Atlantic City borehole. In addition, we show cumulative percentage data of the medium-coarse quartz sand, fine quartz sand, silt-clay, glauconite sand, and shell components for the Atlantic City and Cape May boreholes (Figs. 4, 5). The percent silt-clay was determined quantitatively from samples washed through a $63-\mu \mathrm{m}$ sieve for foraminiferal studies. In sections with glauconite, the abundances of other components were visually estimated from the greater than $63-\mu \mathrm{m}$-size fraction; in sections without glauconite and shell material, the percentages of fine vs. medium-coarse sand were obtained by dry sieving and weighing. Downhole gamma-ray logs were compared with the lithofacies descriptions at all three boreholes (Figs. 4-9). Facies interpretations follow the depositional models outlined by Owens and Sohl (1969), Owens and Gohn (1985), and Owens et al. (1988) who recognized transgressive/ regressive facies successions in the New Jersey Coastal Plain influenced by deltaic deposition.

Lower to middle Miocene sands and clays in both outcrop and subsurface of New Jersey are generally assigned to the Kirkwood Formation (e.g., Sugarman et al., 1993). Owens et al. (1995) subdivided these sediments, recognizing four formations increasing in age: Belleplain, Wildwood, Shiloh Marl, and Kirkwood. These lithostratigraphic units are also equivalent to the $\mathrm{Kw} 3, \mathrm{Kw} 2 \mathrm{a}$ and $\mathrm{Kw} 2 \mathrm{~b}$, Kw1b, and Kw1a and Kw0, respectively, of Sugarman et al. (1993), Miller and Sugarman (1995), and this report. In this paper, we retain the older definition of the Kirkwood Formation and recognize Owens et al.'s (1995) lithostratigraphic units as members of the Kirkwood Formation (Fig. 5). We discuss the rationale for this nomenclature and name the most widespread unit the Brigantine Member in the
Appendix. Miller, et al. (1996a) assigned the youngest fossiliferous middle Miocene sequence sampled in New Jersey $(\sim 11-12 \mathrm{Ma})$ at Cape May to the Kirkwood Formation; however, it is possible that this unit is the fully marine equivalent of the near-shore Cohansey Formation, so they termed this unit the Kirkwood-Cohansey sequence (Kw-Cohansey).

\section{Benthic Foraminiferal Biofacies}

Samples obtained for benthic foraminiferal studies were soaked in $3 \%$ hydrogen peroxide solution, washed with sodium metaphosphate through a $63-\mu \mathrm{m}$ sieve, and floated in a heavy liquid (perchloroethylene). When initial samples proved to be fossil poor, additional samples were washed only with tap water and sodium metaphosphate, because it was feared that hydrogen peroxide might interact with sulfides to dissolve/etch foraminifers. Both float and residue were picked for benthic foraminifers. Generic identifications of benthic foraminifers are based on the taxonomy of Loeblich and Tappan $(1964,1988)$. Species were identified using the taxonomy of Cushman and Cahill (1933), Cushman and Stainforth (1945), Butt (1966), Schnitker (1970), Boersma (1984), and Snyder et al. (1988).

We examined samples from the Atlantic City and Island Beach boreholes at $\sim 10$-ft intervals $(3 \mathrm{~m})$ from 530 to $937 \mathrm{ft}(161.6-285.7$ $\mathrm{m})$ and 430 to $505 \mathrm{ft}(131.1-154.0 \mathrm{~m})$, respectively. Samples from these two boreholes are fossil poor; of the initial 74 samples taken at Island Beach and Atlantic City, only eight yielded over 100 foraminifers. Only samples from the base of the Miocene at Island Beach (the Kw1a sequence; Fig. 4) and the Kw0, Kw1a, and Kw2a sequences at Atlantic City (Fig. 5) contained benthic foraminifers. These samples 
were dominated by Bulimina gracilis, Uvigerina, and Nonionellina (Fig. 5); the generic predominance biofacies (sensu Poag, 1981) based on examination of the greater than $63-\mu \mathrm{m}$-size fraction are illustrated (Fig. 5), and no further studies were conducted.

Although benthic foraminiferal abundances are generally low in Miocene sediments at Cape May, they are sufficiently common for quantitative analysis of the greater than $150-\mu \mathrm{m}$-size fraction. Relative percentage data were computed for samples with more than 50 specimens per sample. This is true except for percent of Elphidium spp. (Figs. 7, 10). The percent of Elphidium was computed for all samples, because this taxon provides a good indicator of the shallowest marine depths and marginal environments (bays, estuaries); nevertheless, only samples with greater than 50 specimens were used in factor analysis. Relative percentage data will be archived with NGDC. Q-mode factor analysis was performed on percentage data from 25 lower to middle Miocene Cape May samples. Principal components were extracted and factors were obtained with a Varimax factor rotation using Systat 5.2.1 on a Macintosh microcomputer (Table 1). Four factors were rotated, explaining $83.5 \%$ of the faunal variation. These factors are interpreted as biofacies. To relate samples with few (10-50) specimens to our biofacies, cluster analysis was performed using Systat 5.2.1 on all samples containing more than ten specimens. Cluster analysis was conducted on total abundance data with a Pearson correlation coefficient using the Ward minimum variance method to resolve clusters (Table 1). Cluster analysis of even these sparse samples generally yielded interpretable results (i.e., they reflect the predominant taxa, Table 1), except for Cluster d, which was not readily interpretable.

Paleodepth estimates for each biofacies were obtained using bathymetric distribution data for modern and fossil benthic foraminifera (Bandy and Arnal, 1957; Smith, 1964; Walton, 1964; Poag, 1981; Sen Gupta and Kilborne, 1976; and Murray, 1991). However, water depth is only one of several factors controlling benthic foraminiferal distributions, and independent paleobathymetric calibrations are needed. Lithofacies data can also be used to calibrate the paleoenvironments of the biofacies in sequences where foraminifers are abundant and the lithofacies interpretations are unambiguous (e.g., the Kwla sequence at Cape May; Figs. 6, 7); these calibrations can be applied to other sequences. Stratigraphic position and biofacies successions can be used to infer relative paleodepths; for example, upsection shallowing within sequences inferred from lithofacies and well-log interpretations are often associated with clear faunal successions (e.g., the Kw1a sequence; Figs. 6, 7). Finally, projections of the sites along a paleoslope profile (Fig. 1) can be used to place relative paleodepth constraints (see Olsson et al., 1987 for method). The bathymetric zonation of van Morkhoven et al. (1986) is used: 0-30 m is inner neritic, $30-100 \mathrm{~m}$ is middle neritic, and $100-200 \mathrm{~m}$ is outer neritic.

\section{Age Control}

Sr-isotopic stratigraphy was developed by Miller, et al. (1994, 1996a) and Sugarman et al. (Chapter 12, this volume) and tabulated in Sugarman et al. (Chapter 12, this volume; see their table 1). Srisotope analyses were made on calcareous mollusk shells and one foraminiferal sample. A piece $5 \mathrm{~mm}$ in diameter was taken from the most pristine part of the shell and ultrasonically cleaned in distilled water for 5-10 s, crushed, and dissolved in 1.5-N HCl. Standard ionexchange techniques (Hart and Brooks, 1974) were used to separate strontium for analysis on a VG Sector mass spectrometer at Rutgers University. At Rutgers, NBS-987 is measured as $0.710255{ }^{87} \mathrm{Sr} /{ }^{86} \mathrm{Sr}$ (20 analyses, $1 \sigma= \pm 0.000008$, normalized to ${ }^{86} \mathrm{Sr} /{ }^{88} \mathrm{Sr}=0.1194$ ) during analysis of Leg $150 \mathrm{X}$ samples. Two recent measurements on EN1 , an informal Sr-isotope standard, are $0.709196 \pm 9$ and $0.709186 \pm 6$. Average internal error (intrarun variability) on the samples considered here was \pm 0.000009 . External error at Rutgers is estimated as \pm 0.000020 based on the average error of 17 duplicate analyses (Oslick et al., 1994). Ages were assigned using both the Berggren et al. (1985; BVK85) and Cande and Kent (1992; CK92) time scales using the calibration of Oslick et al. (1994). In this paper, we plot ages derived from the Oslick et al. (1994) calibration against the Berggren et al. (1995; BKSA95) time scale (Figs. 2, 3). There are minor differences between the CK92 and BKSA95 in the Miocene, and future studies are needed to revise the calibration of Oslick et al. (1994). The calibration to the CK92 time scale has age resolution of $\pm 0.6-0.4$ m.y. for the early Miocene and $\pm 1.2-0.8$ m.y. for the middle Miocene at the $95 \%$ confidence interval using 1 and 3 analyses per level, respectively (Oslick et al., 1994).

Planktonic foraminiferal biostratigraphy supplements Miocene Sr-isotopic stratigraphic control at Cape May (Liu et al., Chapter 10, this volume; Fig. 3). Shallow marine paleoenvironments and temperate climate exclude most primary tropical/subtropical zonal markers. Planktonic foraminifers are very rare in the Miocene at Island Beach and Atlantic City, but are more abundant at Cape May. The only primary zonal marker found in the Miocene section, Paragloborotalia mayeri, appears to have a premature highest occurrence (Fig. 3, i.e., its highest occurrence is in the Kw3 sequence whereas $\mathrm{Sr}$-isotopic stratigraphy predicts it should range to the top of the Kw-Cohansey sequence). Nevertheless, several secondary markers whose ranges are calibrated to the BKSA95 time scale appear to be useful: the highest occurrences of Globigerina angulisuturalis and Tenuitella munda and the lowest occurrences of Globorotanella praescitula and Globigerinoides altiapertura (Fig. 3). We calibrated the highest occurrence of Paragloborotalia opima nana to the time scale (22 Ma) using the magnetobiostratigraphy at Site 563 (Miller et al., 1985) and used it in our age-depth comparisons (Fig. 3).

\section{RESULTS \\ Chronology and Sedimentation Rates of Miocene Sequences}

Miocene sediments in the coastal plain are difficult to date using biostratigraphy or magnetostratigraphy because deltaic influences and shallow-water paleoenvironments exclude pelagic biostratigraphic markers, and magnetostratigraphy is difficult in the coarse sediments (Miller et al., 1990). Thus, the chronology of the Miocene onshore sequences is primarily derived using $\mathrm{Sr}$-isotopic stratigraphy.

The chronology of the lower Miocene Kw0, Kw1a, Kw1b, and $\mathrm{Kw} 2 \mathrm{a}$ sequences is constrained well at Atlantic City by $\mathrm{Sr}$-isotopic stratigraphy (Fig. 2). The Kw0 sequence (914.4-888 ft [278.8-270.7 $\mathrm{m}]$ ) was deposited between 21.9 and $23.6 \mathrm{Ma}$ at a rate of $5 \mathrm{~m} / \mathrm{m} . \mathrm{y}$. Sedimentation rates increased dramatically to over $40 \mathrm{~m} / \mathrm{m}$.y. by the time Kw1a was deposited (20.1-21.1 Ma); this increase in sedimentation rates coincides with a fundamental switch in sediment type from neritic glauconites of Kw0 and older sequences to clastic shelf and deltaic-influenced deposition during Kw1 and younger sequences. There is no discernible hiatus associated with the disconformity separating Kw1a (20.1-21.1 Ma; 888-741 ft [270.7-225.9 m]) and Kw1b (19.5-20.1 Ma; 741-666 ft [225.9-203.0 m]). The surface is dated as $20.1 \mathrm{Ma}$ at Atlantic City based on interpolation of sedimentation rates, in excellent agreement with its age at Cape May. Sedimentation rates remained high $(43 \mathrm{~m} / \mathrm{m}$.y.) during deposition of the uppermost lower Miocene Kw2a sequence (16.1-17.8 Ma; 666-512 ft [203.0-156.1 m]).

Only two middle Miocene sequences were recovered at Atlantic City, Kw2b and Kw3 (Fig. 2). The Kw2b sequence (15.7-16.1 Ma; $512-470 \mathrm{ft}[203.0-143.3 \mathrm{~m}])$ was deposited at slightly lower sedimentation rates $(32 \mathrm{~m} / \mathrm{m}$.y.) than sequences above and below; this sequence is probably truncated as indicated by a thin HST (Fig. 5). The Kw3 sequence is dated as 13.4-13.8 Ma at Atlantic City (470-?375 


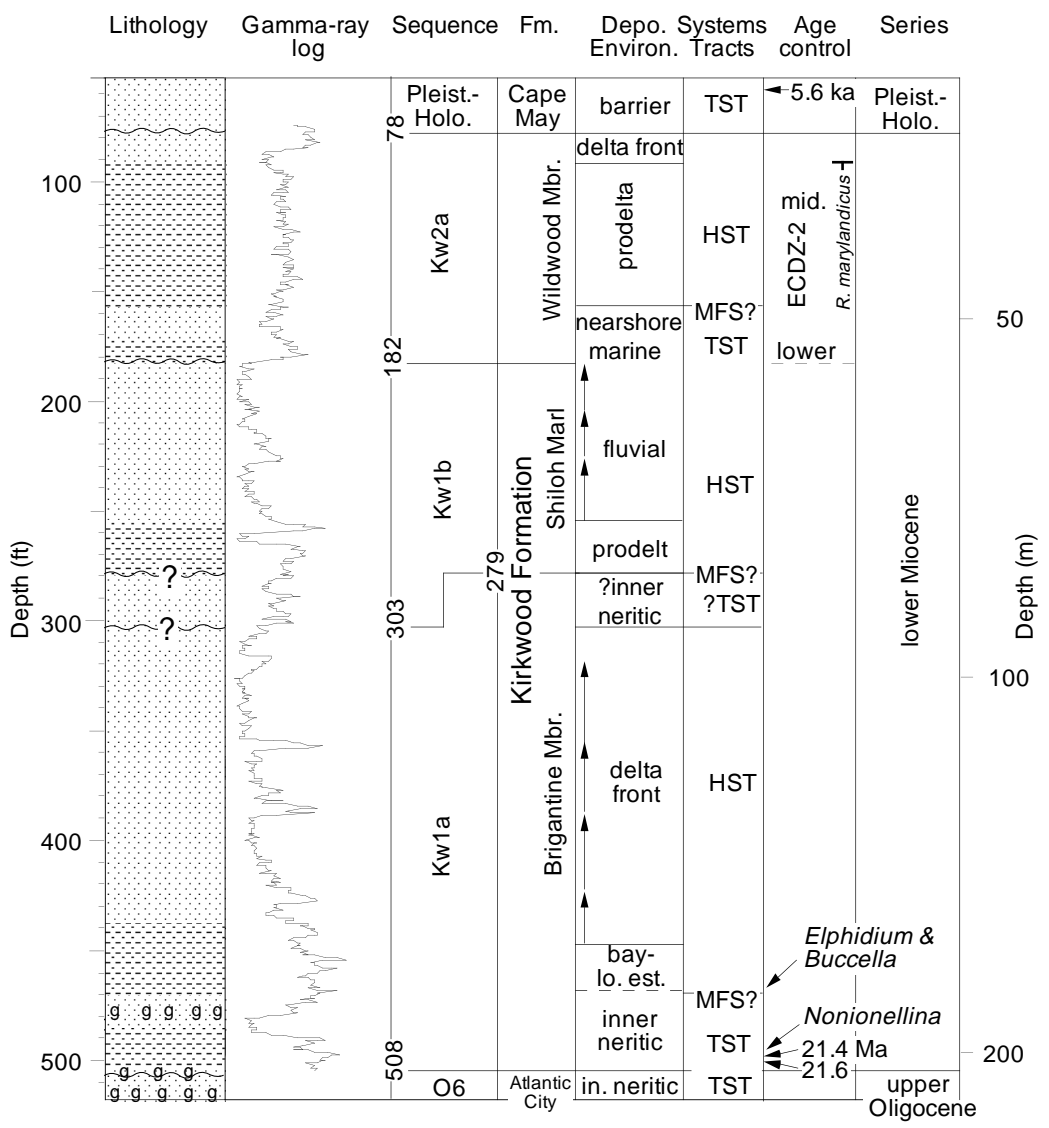

Figure 4. Lithofacies interpretation of the Island Beach borehole modified after Miller, et al. (1994), Sugarman and Miller (1997), and Owens et al. (Chapter 2, this volume). Arrows indicate coarsening-upward parasequences. Fm = Formation, HST $=$ Highstand Systems Tracts, TST $=$ Transgressive Systems Tracts, MFS = Maximum Flooding Surfaces, and ECDZ-2 = East Coast Diatom Zone 2. See Figure 2 caption for further explanation. ft) where it was deposited at high sedimentation rates ( $46 \mathrm{~m} / \mathrm{m}$.y.). Although dates on this sequence group tightly (Fig. 2), the ages of this sequence are less certain because $\mathrm{Sr}$-isotopic resolution for the interval younger than $\sim 15.2 \mathrm{Ma}$ is much lower than for the older part of the Miocene ( \pm 1.2 vs. \pm 0.6 m.y. for a single analysis)

At Cape May, the chronology of the lower Miocene Kw0, Kw1a, $\mathrm{Kw} 1 \mathrm{~b}$, and $\mathrm{Kw} 2 \mathrm{a}$ sequences is particularly well constrained; in addition, a previously unrecognized sequence, Kw1c, is well dated (Fig. $3)$. Sedimentation rates were relatively high (14-24 m/m.y., depending on the age model) during deposition of the Kw0 sequence (1180$1062 \mathrm{ft}$ [359.8-323.8 m]). This is surprising considering the common glauconite in the section and the low sedimentation rates for the Kw0 sequence at Atlantic City; glauconite often typifies sections with very slow sedimentation rates (5-10 m/m.y.; e.g., Loutit et al., 1988; Sugarman et al., 1995). However, most of this glauconite in Kw0 at Cape May is recycled, and thus the high sedimentation rate is due to high siliciclastic input in the earliest Miocene. This also indicates a distinctly different sediment source for Cape May vs. Atlantic City during Kw0, when the former had rapid sedimentation, while the latter was starved. The age of the base of this sequence could be as old as 24.5 Ma, although an age of $23.5 \mathrm{Ma}$, as provided by the high sedimentation rate model (Fig. 3), fits better with the age of the sequence at Atlantic City and is well within the errors in the Sr-isotopic ages. Magnetostratigraphy indicates several polarity changes in Kw0 that could be interpreted as Chrons C6An? to C6Ar?, assuming continuous deposition (open symbols, Fig. 3; Van Fossen, Chapter 22, this volume). However, Sr-isotopes indicate a hiatus from 20.8 to $22 \mathrm{Ma}$ at $1062 \mathrm{ft}$, which indicates that the chronozones are older than C6Ar. We interpret these as Chrons C6An and C6Ar, consistent with the Srisotopic data. This interpretation is consistent with the more rapid accumulation rate $(24 \mathrm{~m} / \mathrm{m}$.y.; solid line in Fig. 3) and makes the age of the base of the sequence $\sim 23.5 \mathrm{Ma}$. The top of the sequence is $22 \mathrm{Ma}$ and is well constrained by $\mathrm{Sr}$ isotopes and the highest occurrence of P. opima nana (Fig. 3).

At Cape May, two sedimentation rates are possible for the three lower Miocene Kw1 sequences: Kw1a (1062-942 ft [323.8-287.2 $\mathrm{m}]), \mathrm{Kw} 1 \mathrm{~b}(942-850 \mathrm{ft}[287.2-259.1 \mathrm{~m}])$, and Kw1c $(850-710 \mathrm{ft}$ [259.1-216.5 m]). The lower rate $(42 \mathrm{~m} / \mathrm{m} . \mathrm{y}$.; dashed line, Fig. 3) provides a fit through the $\mathrm{Sr}$-isotopic data within the errors (with one exception), indicates no discernible gaps at the $\mathrm{Kw} 1 \mathrm{a} / \mathrm{Kw} 1 \mathrm{~b}$ and $\mathrm{Kw} 1 \mathrm{~b} / \mathrm{Kw} 1 \mathrm{c}$ sequence boundaries, and requires that the $\mathrm{Kw} 1 \mathrm{a} / \mathrm{Kw} 1 \mathrm{~b}$ boundary is 0.2 m.y. younger at Cape May than at Atlantic City. We prefer a higher sedimentation rate for the Kwla and Kw $1 \mathrm{~b}$ sequences ( $90 \mathrm{~m} / \mathrm{m} . \mathrm{y}$.$) , which provides a best fit for the \mathrm{Sr}$-isotopic data and makes the sequence boundary exactly the same age at both sites. This model indicates a short hiatus (19.4-19.8 Ma) for the Kw1b/Kw1c sequence boundary. Magnetostratigraphy of the Kw1a sequence (Van Fossen, Chapter 22, this volume) is consistent with either model (Fig. 3).There is a hiatus from $\sim 18.3$ to $17.5 \mathrm{Ma}$ at the $\mathrm{Kw} 1 \mathrm{c} / \mathrm{Kw} 2 \mathrm{a}$ boundary, and sedimentation rates in Kw1c were high (42 m/m.y.). Sedimentation rates in the Kw2a sequence (710-615 ft [216.5-187.5 $\mathrm{m}]$ ) are uncertain because of the lack of dates from the sandy upper part of the sequence. A minimum of $20 \mathrm{~m} / \mathrm{m}$.y. is obtained if no discernible hiatus between $\mathrm{Kw} 2 \mathrm{a}$ and $\mathrm{Kw} 2 \mathrm{~b}$ is assumed (dashed line, Fig. 3). Assuming the same sedimentation rate as in the underlying sequence $(42 \mathrm{~m} / \mathrm{m} . \mathrm{y}$.), a hiatus is indicated at the $\mathrm{Kw} 2 \mathrm{a} / \mathrm{Kw} 2 \mathrm{~b}$ boundary (16.1-16.5 Ma; solid line, Fig. 3).

The age control on lower middle Miocene sequences Kw2b (615?576 ft [187.5-175.6. m]), Kw2c (?576-503 ft [175.6-153.4 m]), and $\mathrm{Kw} 3(505-432 \mathrm{ft}[153.4-131.7 \mathrm{~m}])$ is less certain than below because of a thin, truncated Kw2b sequence, and because Sr-isotopic age resolution is lower for this interval. The Kw2b sequence appears to be 15.7-16.1 Ma at Cape May, in remarkable agreement with Atlantic City and elsewhere (Sugarman et al., 1993). Sedimentation 
rates are difficult to determine in this thin sequence, but they are consistent with rates of 20-42 m/m.y. that are estimated in the underlying sequences (Fig. 3). The age of the Kw2c sequence is uncertain; this is the only site that has recovered sediments of this age ( 14-15 Ma). At least three age models are possible for Kw2c (Fig. 3). We prefer one (solid line, Fig. 3) that satisfies all four Sr-isotopic ages, assumes a sedimentation rate of $42 \mathrm{~m} / \mathrm{m}$.y. (as in the sequence below), dates the sequence as $14.3-14.8 \mathrm{Ma}$, places a hiatus from 14.8 to $15.7 \mathrm{Ma}$ at the $\mathrm{Kw} 2 \mathrm{~b} / \mathrm{Kw} 2 \mathrm{c}$ boundary, and places a hiatus of $13.8-14.3 \mathrm{Ma}$ at the Kw2c/Kw3 boundary. The Kw3 sequence is not dated at Cape May because of scarcity of shells; we assume the same ages for this sequence as at Atlantic City (13.4-13.8 Ma), resulting in a sedimentation rate of $42 \mathrm{~m} / \mathrm{m}$.y.

The Kw-Cohansey sequence (base taken at $432 \mathrm{ft}$ [131.7 m]; top at $357 \mathrm{ft}[108.8 \mathrm{~m}]$ ) also was not previously recognized in the New Jersey Coastal Plain. Discarding one anomalous age based on a stratigraphic age inversion (cross hatched in Fig. 3), this sequence ranges from 11.5 to $12.1 \mathrm{Ma}$ with a sedimentation rate of $42 \mathrm{~m} / \mathrm{m} . \mathrm{y}$.

Thus, at Cape May, Miocene sedimentation rates were generally the highest of the three boreholes (24-90 m/m.y.), and the Miocene section was the most complete because of its downdip/downbasin location. Sedimentation rates are surprisingly constant between and within sequences. Following the initiation of deltaic sedimentation between 21 and $22 \mathrm{Ma}$, our data from Cape May could be fit by a uniform sedimentation rate of $42 \mathrm{~m} / \mathrm{m}$.y. that is broken by hiatuses. Based on geologic evidence, we suggest that sedimentation rates were higher during Kw1a and Kw1b time ( $90 \mathrm{~m} / \mathrm{m} . \mathrm{y}$.), but were still $\sim 42 \mathrm{~m} / \mathrm{m}$.y. after this (i.e., from $\sim 11.5$ to $19.0 \mathrm{Ma}$ ). Our data do not indicate increased sedimentation rates during the upper HST (i.e., during input of sands) as was observed for Cretaceous sequences in New Jersey (Sugarman et al., 1995); however, we clearly lack sufficient time resolution to detect these upper HST increases. Miocene sequences are typically $\sim 1 \mathrm{~m}$.y. in duration, and resolution much better than 0.5 m.y. is needed to detect such changes; in contrast, Upper Cretaceous sequences were much longer (Sugarman et al., 1995).

Age control on Island Beach Miocene sequences is limited (Fig. 4). Two Sr-isotopic age estimates at the base (21.4 and 21.6 Ma) indicate that the thick coarsening-upward succession from 508 to 303 $\mathrm{ft}(154.9-92.4 \mathrm{~m})$ is the Kw1a sequence. The identification of middle to lower East Coast Diatom Zone 2 between 182 and $78 \mathrm{ft}$ (55.5 and $23.8 \mathrm{~m}$; L. Burckle in Miller, et al., 1994) indicates that this is the Kw2a sequence and that younger Miocene sequences have been truncated at this location. Although there is no primary age control on the section from 303 to $182 \mathrm{ft}(92.4-55.5 \mathrm{~m})$, superposition indicates that this is most likely the Kw1b sequence (Fig. 4).

\section{Benthic Foraminiferal Biofacies}

Lower to middle Miocene onshore sequences of the Kirkwood Formation are so poorly fossiliferous that little has been known about Miocene benthic foraminiferal biofacies in New Jersey. Coeval sections in Maryland were deposited in deeper water, providing a glimpse of Miocene biofacies (Gibson, 1971) and their sequence stratigraphic succession (Olsson et al., 1987). Our continuously cored records allow us to develop a paleodepth model for inner to middle neritic biofacies in New Jersey for the first time.

Factor, cluster, and dominant species analyses were combined to identify natural groups (biofacies; Table 1). Biofacies in the Miocene sections are strongly dominated by a single species, reflecting the low diversity and high dominance typical of shallow-water (inner to middle neritic) environments (Murray, 1991).

We constructed a biofacies paleodepth model based on distribution of species within the Kwla sequence at all three boreholes (Figs. 4-9). We assume a paleoslope gradient of 1:1000 (similar to the modern shelf gradient), yielding a projected depth difference of $\sim 25$ and $40 \mathrm{~m}$ between Island Beach and Atlantic City, and Island Beach and Cape May, respectively. We note the following upsection patterns:
1. Above the Kw1a MFS, Elphidium $(<10 \mathrm{~m})$ is found at Island Beach, whereas Nonionellina dominates at Atlantic City and Cape May ( 25 to $50-\mathrm{m}$ paleodepths based on projection, respectively).

2. At the base of the sequence, Nonionellina dominates at Island Beach, whereas Bulimina gracilis dominates at the two downdip sites, yielding a depth estimate of $\sim 50-80 \mathrm{~m}$ for the $B$. gracilis biofacies.

3. At the MFS, the section at Island Beach is barren of foraminifers due to dissolution, but is probably at least middle neritic paleodepth $(? 50 \mathrm{~m})$ based on the presence of glauconite (McRae, 1972). The coeval MFSs at the two downdip boreholes are dominated by Uvigerina, yielding a minimum estimate of 75-100 m for the Uvigerina biofacies.

4. Hanzawaia cf. H. hughesi appears at the top of the sequence at Cape May and is clearly shallower than Nonionellina, but deeper than the Elphidium biofacies. We discuss these biofacies from shallowest to deepest below.

\section{Elphidium Biofacies}

An Elphidium-dominated biofacies is interpreted as an indicator of near-shore paleoenvironments, including lower estuarine, bay, and innermost neritic environments ( $<10-\mathrm{m}$ paleodepth). This biofacies is recognized only qualitatively because samples dominated by this taxon generally have few foraminifers. On the deeper end, this biofacies intergrades with the Hanzawaia $\mathrm{cf}$. H. hughesi biofacies (10-25 m), whereas on the shallower end the dominance of Elphidium indicates lower estuarine/bay/near-shore $(<10 \mathrm{~m})$ environments (Murray, 1991).

\section{Hanzawaia $c f$. H. hughesi Biofacies}

A Hanzawaia cf. H. hughesi biofacies often containing Elphidium characterizes inner neritic paleodepths from 10 to $25 \mathrm{~m}$ (inner neritic). This biofacies is the shallowest-water assemblage defined by factor/cluster analysis in the New Jersey Miocene. It is represented by Factor 3, explains $12.4 \%$ of the faunal variation, and is dominated by Hanzawaia cf. H. hughesi (score 9.6, mean abundance 52\%). This biofacies is also characterized by the absence of Nonionellina pizarrensis (score of -1.46). The $H$. cf. $H$. hughesi biofacies is present at the top of Kw1a (945 ft, 288.0 m) and the base of Kw2a (690-672 ft [210.3-204.8 m]). Modern Hanzawaia are found primarily on the inner shelf (Murray, 1991). Based on this, the general location of this biofacies within the individual sequences, and our paleoslope model, the paleobathymetry for this grouping is estimated to be inner neritic (10-25 m).

\section{Nonionellina Biofacies}

A Nonionellina spp. (N. grateloupi and N. pizarrensis) biofacies characterizes paleodepths of 25-50 m (outer inner to inner middle neritic). This biofacies can be divided into a slightly shallower Nonionellina pizarrensis biofacies and a deeper $N$. grateloupi biofacies. The $N$. pizarrensis biofacies is defined by Factor 4 and explains $23.4 \%$ of the faunal variation. It is found at the top of Kw0 $(1066.8 \mathrm{ft}$ [325.2 m]), in Kw1a (1000-1030 ft [304.8-313.9 m]), and in Kw1b $(880 \mathrm{ft}[268.2 \mathrm{~m}])$ and is dominated by Nonionellina pizarrensis (score $=9.5$, mean abundance $=9 \%$ ) and Hanzawaia cf. hughesi (score $=1.5$, mean abundance $=12 \%)$. The Nonionellina grateloupi biofacies is defined by Factor 2 (score $=9.53$, mean abundance $=$ $50 \%$ ) and explains $26.1 \%$ of the faunal variation. Nonionellina pizarrensis (score $=1.9$, mean abundance $=16 \%$ ) is also an important taxon. It is observed in Sequences Kw1a (1046-1022 ft [318.8-311.5 $\mathrm{m}]), \mathrm{Kw} 1 \mathrm{~b}(890 \mathrm{ft}$ [271.3 m]), and Kw2c (522 ft [159.1 m]).

Both $N$. pizarrensis and $N$. grateloupi are most common in finegrained quartz sands, silts, and clays and are inner to middle neritic 


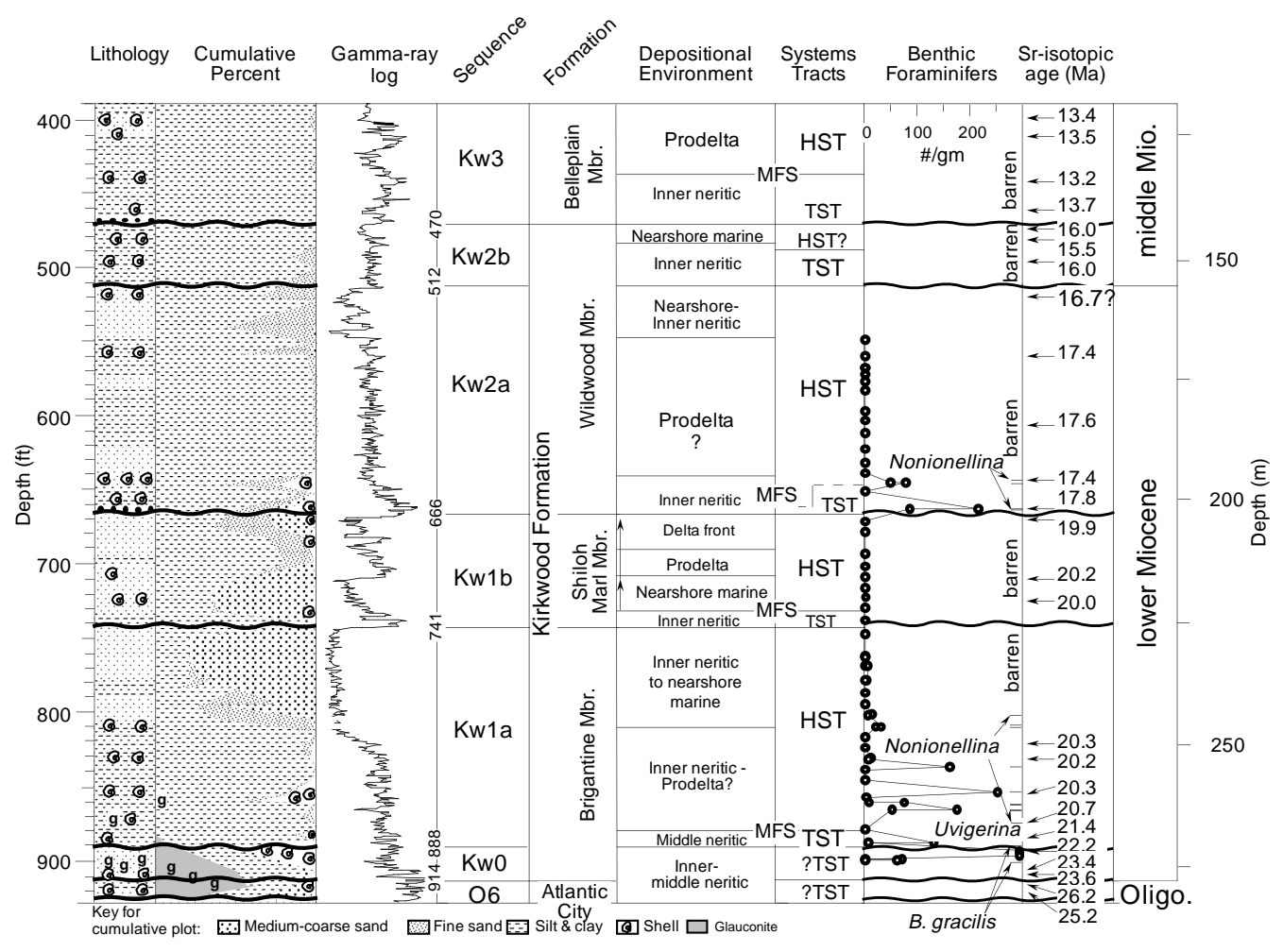

Figure 5. Lithofacies, paleoenvironments, and systems tracts interpretation of the Atlantic City borehole, modified after Sugarman and Miller (1997), showing cumulative percentage diagram. Key at the bottom is for this and subsequent cumulative percentage diagrams. See Figure 2 caption for further explanation.

taxa. The taxonomically similar Nonionellina atlanticus has a modern depth range of $20-50 \mathrm{~m}$ on the North Carolina shelf, with the highest abundance at $20 \mathrm{~m}$ (Schnitker, 1971). The $N$. grateloupi biofacies is inferred to be slightly deeper (35-50 m?) than the $N$. pizarrensis biofacies (25-40 m?), based on the upsection change from $N$. grateloupi to the $N$. pizarrensis biofacies in the shallowing-upward Kw1a sequence at Cape May. Total faunal abundances are higher in the $N$. grateloupi biofacies than the $N$. pizarrensis biofacies, further indicating a slightly deeper environment.

\section{Bulimina gracilis Biofacies}

A Bulimina gracilis biofacies characterizes middle neritic (50-80 $\mathrm{m})$ paleodepths. This biofacies is defined by Factor 1, explaining $21.6 \%$ of the faunal variation. It is dominated by Bulimina gracilis (score $=9.6$, mean abundance $=34 \%$ ). The morphologically similar Bulimina elongata has a similar depth range of 77-95 $\mathrm{m}$ on the modern Atlantic seaboard of Europe and Africa (Murray, 1991). In fact, Bulimina elongata is probably the senior synonym of $B$. gracilis as indicated by Snyder et al. (1988); however, the type illustration of $B$. elongata d'Orbigny differs from our $B$. gracilis by its curvature. The type specimen of $B$. elongata is lost, and it is not possible to compare our specimens with those of d'Orbigny. This biofacies is generally associated with silty clays and clayey silts, occasionally containing glauconite, consistent with a middle neritic or deeper interpretation. It is present in the lower Kw0 (1162 ft [353.6 m]), Kw1a (1050-1045 $\mathrm{ft}$ [320.1-318.6 m] and 1000-967 ft [304.9-294.8 m]), and Kw1c $(837 \mathrm{ft}[255.1 \mathrm{~m}])$ sequences.

\section{Uvigerina Biofacies}

A uvigerinid biofacies (Uvigerina modeloensis and $U$. juncea) characterizes middle neritic depths greater than $75 \mathrm{~m}$ and is associated with the MFS in the Kwla sequence at both Atlantic City and
Cape May (Figs. 5-7). Uvigerina spp. are lumped together by factor analysis with $B$. gracilis in Factor 1, because they are only found in abundance in this, the deepest sequence of the Miocene. However, Pekar et al. (Chapter 15, this volume) recognize that the Uvigerina biofacies typifies MFSs in the Oligocene of the three boreholes. Environmental conditions associated with MFSs are apparently conducive to uvigerinids (Loutit et al., 1988). For example, in modern environments, $U$. peregrina is often associated with peak organic carbon (Miller and Lohmann, 1982), and a similar ecology has been inferred for other hispido-costate uvigerinids (Boersma, 1984). Peaks in organic carbon are often associated with MFSs, explaining the link to uvigerinids (Loutit et al., 1988).

The relative paleodepths of these biofacies are well constrained; however, the absolute paleodepths assigned depend not only on the paleoslope assumed, but also on differential local tectonic and sedimentation effects. Our boreholes did not sample paleodepths greater than about $100 \mathrm{~m}$ (middle neritic). The Miocene paleoslope model is similar to that of the Oligocene of Pekar et al. (Chapter 15, this volume), with Nonionellina dominating the inner to inner middle neritic and $B$. gracilis the middle neritic zones; however, deeper water (outer neritic) environments are represented in the Oligocene onshore biofacies model, which is more complete (see fig. 4 in Pekar et al., Chapter 15 , this volume). The Miocene benthic biofacies model from Maryland (Olsson et al., 1987) differs, in part, because of the size fraction examined. Olsson et al. (1987) examined the greater than $63-\mu \mathrm{m}$-size fraction; ongoing studies of this size fraction at Cape May will attempt to compare the Maryland and New Jersey biofacies models.

\section{Paleoenvironments and Systems Tracts}

Paleoenvironmental and System Tract interpretations are based on lithofacies, well-log, and benthic foraminiferal biofacies data. Lower to middle Miocene sequences at Cape May, where nine sequences were recognized, are the thickest and the temporally most 


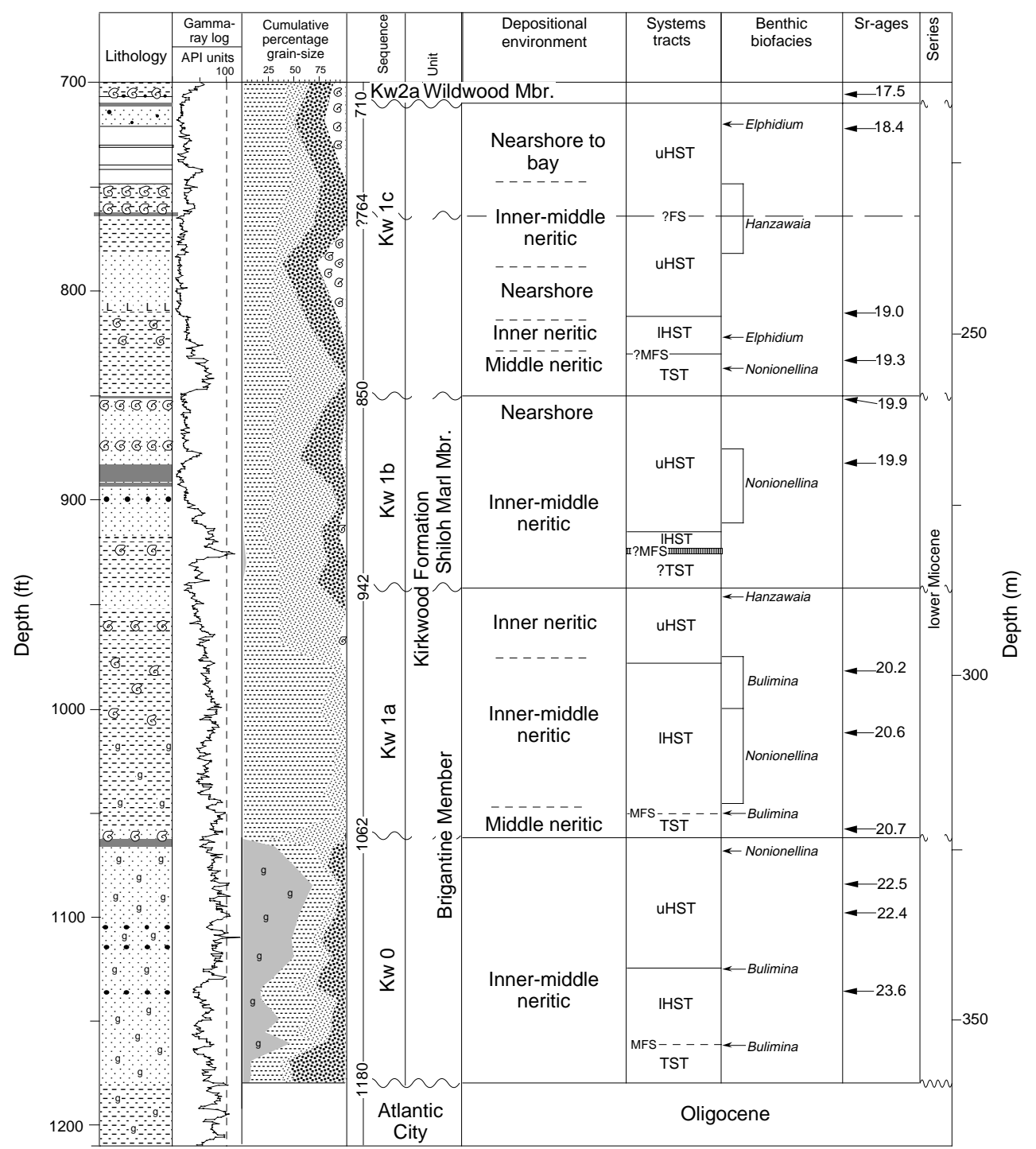

Figure 6. Lithofacies, paleoenvironments, systems tract, and benthic foraminiferal biofacies interpretations of the lower part of the Miocene at the Cape May borehole. The lithology, downhole gamma-ray log, sequences, and Sr-isotopic columns are modified after Miller, et al. (1994); the cumulative percent data, depositional environments, system tracts, factors, and clusters are from this study. Key for cumulative percentage diagram is on Figure 5. See Figure 2 caption for further explanation.

complete, and represent the deepest paleodepths. Atlantic City records six of these sequences (Kw0, Kw1a, Kw1b, Kw2a, Kw2b, Kw3). Only the Kw1a, Kw1b, and Kw2a sequences are represented at Island Beach, the most updip location drilled by Leg 150X. We discuss each sequence individually beginning with those at Cape May.

\section{Kw0}

At Cape May, the Kw0 sequence (1180-1062 ft [359.8-323.8 m]) is a quartzose glauconite sand. Glauconite is high at $1162 \mathrm{ft}(354.3$ $\mathrm{m})$, is minimal from 1162 to $1125 \mathrm{ft}(354.3-343.0 \mathrm{~m})$, and increases upsection above $1125 \mathrm{ft}$ ( $343.0 \mathrm{~m}$; Fig. 6). The glauconites above $1162 \mathrm{ft}(354.3 \mathrm{~m})$ are detrital and not in situ. The MFS is placed at the peak abundance of benthic foraminifers and glauconite at $1162 \mathrm{ft}$, and the section below this is assigned to the TST. A thin lower HST (1162-1125 ft [354.3-343.0 m]) has peak clay-silt values, whereas the increase in glauconite above $1125 \mathrm{ft}(343.0 \mathrm{~m})$ is associated with the upper HST. The detrital glauconites yield high gamma-ray log values in the upper sands (Fig. 6). Low diversity benthic foraminifer- al biofacies indicate that the entire sequence was deposited in innermiddle neritic environments that shallow in the upper HST: Bulimina gracilis (50- to $80-\mathrm{m}$ paleodepth) dominates at the base and the Nonionellina pizarrensis biofacies (25- to 50-m paleodepth; Figs. 6, 7) dominates at the top.

At Atlantic City, the base of the Kw0 sequence $(914.4-888 \mathrm{ft}$ [278.8-270.7 m]) is marked by glauconite sand and a shell bed and consists primarily of silty glauconite sand (Fig. 5). Rare benthic foraminifers (B. gracilis, Cibicides primulus) indicate deposition in inner to middle neritic paleodepths. We attribute the absence of upper quartz sands to erosional truncation and assign the entire sequence to the TST (Fig. 5).

\section{Kw1a}

This is the most widespread of the Kirkwood (Kw) sequences and is well represented at all three boreholes. It is not clear whether the $\mathrm{Kw} 1 \mathrm{a}$ and Kw1b sequences represent true sequences separated by an erosional disconformity caused by a regional lowering of baselevel. 


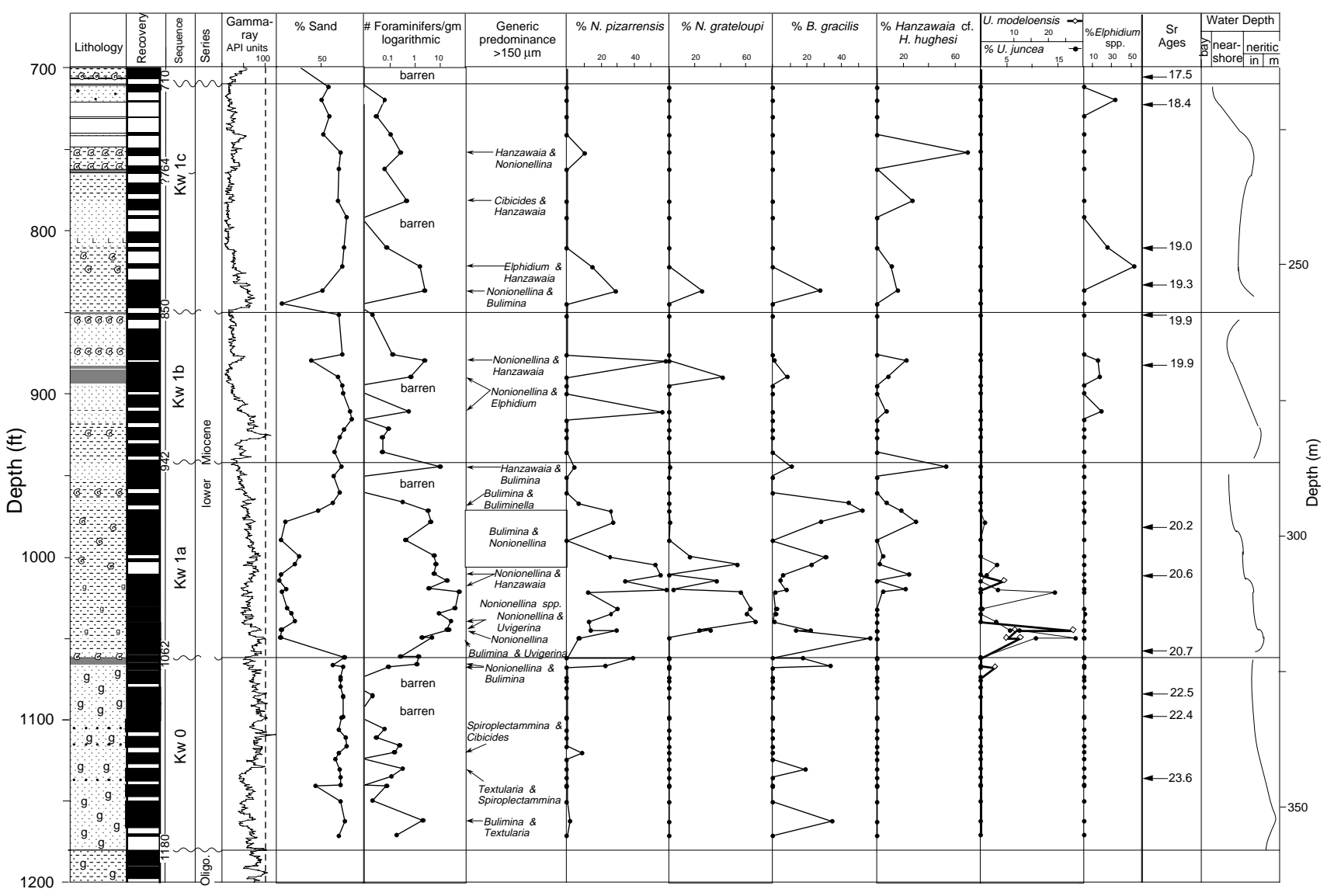

Figure 7. Benthic foraminiferal biofacies results, lower part of Cape May borehole. See Figure 2 caption for further explanation.

As discussed above, this is the only sequence boundary with no discernible hiatus. At Cape May (Fig. 6), the Kw1b facies could be interpreted as a parasequence genetically related to the Kw1a sequence. Nevertheless, there is a distinct surface of erosion associated with the $\mathrm{Kw} 1 \mathrm{a} / \mathrm{K} 1 \mathrm{~b}$ boundary at all three boreholes, and we follow Sugarman et al. (1993) and Owens et al. (1995) in recognizing Kw1a and Kw1b as distinct mappable sequences and lithostratigraphic units (e.g., the Brigantine and Shiloh Marl Members; see Appendix).

At Cape May (Fig. 6), the Kw1a sequence (1062-942 ft [323.8$287.7 \mathrm{~m}]$ ) consists of a basal shell bed (TST), a thick medial silt-clay (lower HST; 1058-975 ft [322.6-297.3 m]) and a coarseningupward upper quartz sand (upper HST; 975-942 ft [297.3-287.2 m]). $\mathrm{Kw} 1 \mathrm{a}$ is the most fossiliferous sequence in the Miocene:

1. Bulimina gracilis dominates the basal part (Fig. 7).

2. A peak in Uvigerina marks the MFS, although Bulimina is still the dominant taxon at this level (Fig. 7).

3. Nonionellina dominates the medial portion, primarily in the silt-clays (Fig. 7).

4. B. gracilis and Hanzawaia cf. H. hughesi are found in abundance in some of the sands, although the upper HST quartz sands are mostly barren (Fig. 7).

This clear faunal succession represents a transgression from inner middle neritic (50-80 $\mathrm{m}$ ) in the TST to outer middle neritic (75-100 $\mathrm{m})$ at the MFS, with a subsequent regression to inner neritic (25-50 $\mathrm{m}$ ) in the lower HST. The recurrence of the $B$. gracilis biofacies in the HST may mark a flooding surface, whereas the presence of Hanzawaia $\mathrm{cf}$. H. hughesi marks a regression to innermost neritic environments $(\sim 10-25 \mathrm{~m})$.

At Atlantic City (Fig. 5), the Kw1a sequence (888-741 ft [270.7$225.9 \mathrm{~m}]$ ) is lithologically similar to that at Cape May. It has a glau- conitic bed with reworked shells at the base $(888 \mathrm{ft}$ [270.7 m]). Benthic foraminifers in this section are dominated by a middle neritic $B$. gracilis biofacies that are assigned to the TST (Fig. 5). This is overlain by burrowed clay-silt to silty sand and laminated clay-silt that extends to $808 \mathrm{ft}(246.3 \mathrm{~m})$, typically with thin dispersed shell hash. Benthic foraminifers in this section show a peak in Uvigerina $(880 \mathrm{ft}$ [268.3 m]) that is interpreted as the deepest paleodepths (middle neritic; $75-100 \mathrm{~m}$ ) and the MFS; this is overlain by a Nonionellina biofacies (inner-middle neritic) and the regressive lower HST (Fig. 5). The upper facies of the Kwla sequence consist of fine- to mediumgrained quartz sand grading-upward into a massive coarse quartz sand (808-741 ft [246.3-225.9 m]) deposited in the regressive upper HST (Fig. 5). The presence of weathered carbonate, sparse diatoms, and lack of carbonaceous material and mica indicates near-shore to inner neritic environments with minimal deltaic influence at this site. The absence of benthic foraminifers is attributed to dissolution in the aquifer sands.

At Island Beach (Fig. 4), Owens et al. (Chapter 2, this volume) place the base of the Kw1a sequence at $508 \mathrm{ft}(154.8 \mathrm{~m})$ and interpret the interval from 508 to $505.5 \mathrm{ft}(154.8-154.1 \mathrm{~m})$ as a basal reworked zone. In contrast, Miller, et al. (1994) place the top of the Oligocene at $505.5 \mathrm{ft}(154.1 \mathrm{~m})$ at the top of glauconite sands. No age control is available to help resolve the placement of this boundary and the glauconite sands between the lowest dated level $(504.5 \mathrm{ft}[153.8 \mathrm{~m}], 21.6$ $\mathrm{Ma})$ and $508 \mathrm{ft}(154.8 \mathrm{~m})$ could be the basal glauconites of this sequence or part of the underlying O6 sequence of Pekar et al. (Chapter 15 , this volume). A shelly silty clay $(505.5-486 \mathrm{ft}[154.1-148.2 \mathrm{~m}])$ is overlain by glauconitic quartz sands (486-475 ft [148.2-144.8 m]) and a coarsening-upward succession of quartz sands $(475-467 \mathrm{ft}$ [144.8-142.4 m]), with a return to silty clays (467-443 ft [142.4$135.1 \mathrm{~m}])$. The basal part of this section $(502 \mathrm{ft}[153.0 \mathrm{~m}])$ contains a Nonionellina pizarrensis fauna (inner-middle neritic), whereas the 
section to $467 \mathrm{ft}(142.4 \mathrm{~m})$ contains abundant wood and mica and sparse benthic foraminifers; at this level, specimens of Elphidium and Buccella indicate shallow-water deposition (bay/lagoon/lower estuarine environments). Based on the lithofacies and benthic foraminiferal evidence, the section to $467 \mathrm{ft}(142.4 \mathrm{~m})$ was deposited in neritic to shallow marine environments that were strongly influenced by a delta and the section above in bay/lagoon/lower estuarine environments. We place the MFS at the top of the glauconites at $475 \mathrm{ft}$ (144.8 $\mathrm{ft}$ ), interpreting the section below as a thin TST and the silty clays above as the lower HST. Sandy silts (467-438 ft [142.4-133.5 m]) grade up to thinly bedded to laminated interbeds of fine-grained micaceous quartz sands and woody micaceous clays/peats $(438-303 \mathrm{ft}$ [133.5-92.4 m]), interpreted as upper HST deposited in a delta-front environment. Gamma-ray logs show at least four cycles of decreasing upsection values in this interval (Fig. 4); we interpret these as coarsening-upward successions (parasequences or fluvial facies successions).

\section{$K w 1 b$}

At Cape May (Fig. 6), the Kwlb sequence (942-850 ft [287.2$259.1 \mathrm{~m}]$ ) is sandy with a sparse fauna; hence, sequence stratigraphic interpretations are less certain than in the underlying $\mathrm{Kw} 1$ a sequence. The lower part (942-916 ft [287.2-279.3 m]) consists of interbedded silty fine sands, sandy silts, and silty clays with high gamma-ray log values (Fig. 6); this section contains a sparse inner to middle neritic fauna (B. gracilis and $N$. pizarrensis) and is interpreted as the TST to lower HST. We tentatively place the MFS at $925 \mathrm{ft}(282.0 \mathrm{~m})$, coincident with a distinct gamma-ray log peak and a shelly zone. The finer beds are overlain by medium to coarse sands of the upper HST, as reflected by minimum gamma-ray log values; a Nonionellina biofacies (910-885 ft [277.4-269.8 m]) with high abundances of Hanzawaia cf. $H$. hughesi, and Elphidium spp. indicates a shallowing to inner neritic paleodepth (Fig. 6). An indurated zone at $893-887 \mathrm{ft}$ (272.3-270.4 m) overlain by a shell bed may represent a flooding surface. The top of the sequence $(885-850 \mathrm{ft}$ [269.8-259.1 m]) consists of shelly sediments containing few foraminifers and was deposited in near-shore environments.

At Atlantic City (Fig. 5), the Kw1b sequence (741-666 ft [225.9$203.4 \mathrm{~m}]$ ) consists of clayey shelly sands and laminated sands and silts that grade upward into massive clayey sands with shells, interbedded sands and lignitic silts, and pebbly sands. The sands in the $\mathrm{Kw} 1 \mathrm{~b}$ sequence at Atlantic City have characteristics of delta front, inner neritic, and near-shore marine environments. Overall we interpret the $\mathrm{Kw} 1 \mathrm{~b}$ as representing shallowing upsection from inner neritic to delta front environments. Well-log and lithofacies data indicate two coarsening-upward parasequences (indicated with arrows on Fig. 5) within this overall succession. The lower parasequence in Kw1b contains shell, with a shell bed at $733.3 \mathrm{ft}(223.6 \mathrm{~m})$ possibly representing the MFS. It is interpreted as inner neritic to near shore, whereas the absence of shells, foraminifers, and diatoms and the interbedded sands and lignitic silts in the upper parasequence support a delta-front environment (Fig. 5).

At Island Beach (Fig. 4), Owens et al. (Chapter 2, this volume) place the contact between the Kw1a sequence and the Kw1b sequence at $303 \mathrm{ft}(92.4 \mathrm{~m})$ and interpret the section to $279 \mathrm{ft}(85.1 \mathrm{~m})$ as inner neritic (TST). The MFS could be at $279 \mathrm{ft}$ at the base of the uniform chocolate silty clays and a gamma-ray log increase (Fig. 4). Although this is reasonable, it is also possible to place the sequence boundary at $279 \mathrm{ft}$ (Fig. 4). No age control is available to help resolve the placement of this boundary. Above $279 \mathrm{ft}$, the Kw1b sequence consists of laminated, woody, burrowed clay-silt containing diatoms from 279 to $256 \mathrm{ft}(85.1-78.0 \mathrm{~m})$ that are interpreted as marine prodelta (lower HST). These are overlain by micaceous, lignitic quartz sands with some local cross bedding and nonmarine coarse clasts with wood as a common component; it is probably a fluvial deposit associated with a delta (upper HST). The downhole gamma-ray log shows three cycles of increasing values upsection; we interpret these as coarsening-upward successions (parasequences or fluvial facies successions).

\section{Kw1c}

The Kw1c sequence (850-710 ft [259.1-216.5 m]) is represented only at Cape May where it comprises a coarsening-upward sequence with a clear faunal succession (Figs. 6, 7). The gamma-ray log shows a clear maximum at the base and decreasing values above from $\sim 830$ to $810 \mathrm{ft}(253.0-247.0 \mathrm{~m})$. This reflects an upsection change from sandy clays at the base $(847-840 \mathrm{ft}[258.2-256.1 \mathrm{~m}])$ to sandy silty clay/clayey silt (840-834 ft [256.1-254.3 m]), shelly, clayey medium sand $(823.2-810 \mathrm{ft}[251.0-247.0 \mathrm{~m}])$, and coarse gravely sands (807.3-781.4 ft [246.1-238.2 m]). We tentatively place the MFS at $835 \mathrm{ft}(254.6 \mathrm{~m})$ at the maximum abundance of foraminifers and interpret the more clay-rich section from 835 to $810 \mathrm{ft}(254.6-247.0 \mathrm{~m})$ as the lower HST and the sandier section above as the upper HST. A shell bed from 760.9 to $760.2 \mathrm{ft}(232.0-231.8 \mathrm{~m})$ is associated with a gamma-ray log kick and overlies an indurated zone at $764 \mathrm{ft}(232.9$ $\mathrm{m})$. Our interpretation of this as a flooding surface is supported by benthic foraminifers (Fig. 6). Benthic foraminiferal biofacies indicate middle neritic to near-shore to bay environments in a clear succession.

1. At the MFS, a Nonionellina biofacies containing common $B$. gracilis is interpreted as a middle neritic environment $(\sim 60 \mathrm{~m})$.

2. This is overlain by an Elphidium-dominated biofacies with common Hanzawaia cf. H. hughesi interpreted as an inner neritic $(\sim 10-25 \mathrm{~m})$ environment.

3. The reappearance of Nonionella pizarrensis in a Hanzawaia cf. H. hughesi biofacies at $\sim 750 \mathrm{ft}(228.7 \mathrm{~m})$ is associated with a minor deepening to inner-middle neritic paleodepths $(\sim 25 \mathrm{~m})$.

4. The top of the sequence is dominated solely by Elphidium, indicating a bay/lower estuarine environment (Figs. 6, 7).

\section{$K w 2 a$}

At Cape May (Figs. 8, 9), the Kw2a sequence (710-615 ft [216.5$187.5 \mathrm{~m}]$ ) consists of well-developed facies succession in both the TST and HST. The TST consists of the following upsection succession:

1. shelly near-shore sands lacking foraminifers at the base (710$706.2 \mathrm{ft}$ [216.5-215.3 m]);

2. dark gray silty clay $(706.2-690.0 \mathrm{ft}[215.3-210.4 \mathrm{~m}])$;

3. a clayey medium sand (687.6-681.4 ft [209.6-207.7 m]);

4. an indurated sand (681.4-680.1 ft [207.7-207.3 m]); and

5. a shell layer at $680.1 \mathrm{ft}(207.3 \mathrm{~m})$ associated with maximum foraminiferal abundances.

This is interpreted as a transgression from near-shore to inner neritic environments typified by Hanzawaia cf. H. hughesi, Elphidium, and Nonionellina (Figs. 7, 8); it culminates in the MFS at $680 \mathrm{ft}(207.3$ $\mathrm{m})$. The HST facies succession from 680.1 to $617.5 \mathrm{ft}$ (207.3-188.3 $\mathrm{m})$ represents a classic coarsening-upward succession:

1. a basal shell bed (680.1-676.2 ft [206.8-206.2 m]);

2. interbedded fine-medium sands and laminated clay beds and laminated clays with occasional shells $(673.2-648.0 \mathrm{ft}$ [205.2-197.6 m]);

3. primarily fine-medium sands with occasional sandy clay layers (647.5-627.4 ft [197.4-191.2 m]); and

4. a fine-medium sand (627.0-617.5 ft [191.3-188.3 m]).

These facies represent a prograding delta, with more distal prodelta at the base (deposited in inner neritic depths as evidenced by foraminifers) and more proximal delta front sands at the top. 


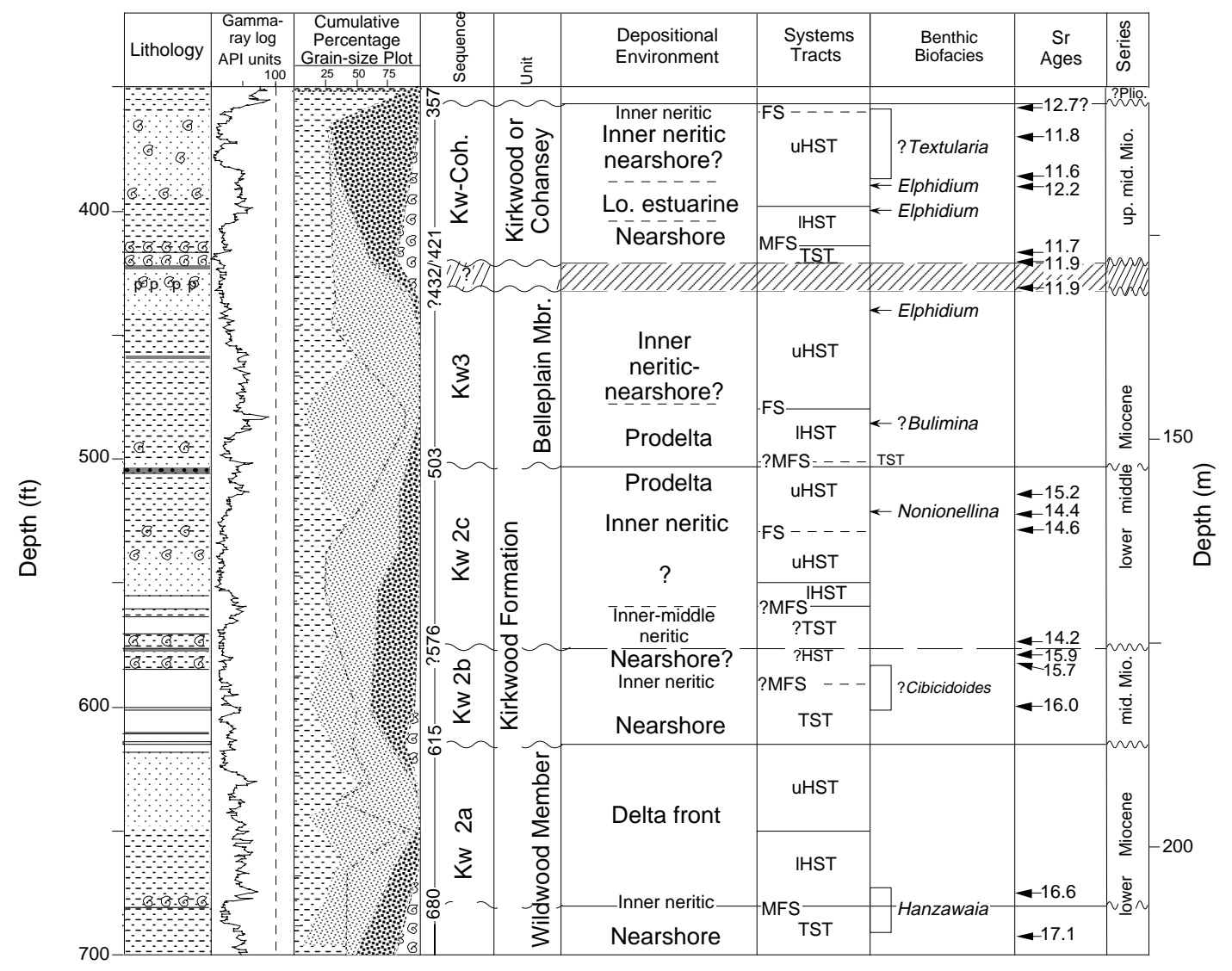

Figure 8. Lithofacies, paleoenvironments, systems tracts, and benthic foraminiferal biofacies interpretations of the upper part of the Miocene at the Cape May borehole. The lithology, downhole gamma-ray log, sequences, and Sr-isotopic columns are modified after Miller, et al. (1994); the cumulative percent data, depositional environments, system tracts, factors, and clusters are from this study. Key for cumulative percentage diagram is on Figure 5. See Figure 2 caption for further explanation.

At Atlantic City (Fig. 5), the Kw2a sequence (666-512 ft [203.0$156.1 \mathrm{~m}])$ consists of basal shelly silty sands $(666-660 \mathrm{ft}[203.0-$ $201.2 \mathrm{~m}]$ ) with inner-middle neritic benthic foraminifers (Nonionellina biofacies; Fig. 5). The MFS is probably near the base of the sequence at the greatest abundance of benthic foraminifers and shells $(663.8 \mathrm{ft}[202.4 \mathrm{~m}])$; alternatively, it could be placed at a secondary peak in both foraminifers and shells at $644 \mathrm{ft}$ (196.3 m; Fig. 5). Silty clays from 664 to $528 \mathrm{ft}(202.4-161.0 \mathrm{~m})$ were deposited in prodelta to inner neritic environments (lower HST). An upper interbedded quartz sand with carbonaceous silts (528-512 ft [161.0-156.1 m]) was deposited in marine environments as indicated by the presence of diatoms and is interpreted as near shore to inner neritic (upper HST).

At Island Beach (Fig. 4), the basal part of the Kw2a sequence $(182-78 \mathrm{ft}[55.5-23.8 \mathrm{~m}])$ is sandy silt $(182-158 \mathrm{ft}[55.5-48.2 \mathrm{~m}])$ overlain by a clayey, well-sorted, fine-grained, micaceous, and woody quartz sand (158-173 ft [48.2-52.7 m]) that contains diatoms. These clays and sands are interpreted as near shore or inner neritic. They are overlain by silty clay with very thin layers of very finegrained quartz sand containing diatoms (158-103 ft [48.2-31.4 m]), interpreted as prodelta and the lower HST. Sands at the top are interpreted as delta front and the upper HST (103-78 ft [31.4-23.8 m])

\section{$K w 2 b$}

At Cape May (Figs. 8, 9), the Kw2b sequence (615-576 ft [187.5$175.6 \mathrm{~m}]$ ) is very poorly recovered. It appears to be a truncated sequence consisting primarily of the TST, as it is at Atlantic City. The presence of a benthic foraminiferal fauna with Quinqueloculina, Cibicides, Elphidium, and $H$. hughesi indicates inner neritic deposition.

At Atlantic City, the Kw2b sequence (512-470 ft [156.1-143.3 $\mathrm{m}]$ ) consists of shelly silty clays (TST-lower HST). It is barren of benthic foraminifers, although the presence of diatoms and shells indicates marine deposition in inner neritic to near-shore environments. No upper sands (upper HST) are present, indicating that the sequence is also truncated at this site.

\section{$K w 2 c$}

The Kw2c sequence $(576-503 \mathrm{ft}[175.6-153.4 \mathrm{~m}])$ is only represented at Cape May (Figs. 8, 9). Inner neritic (Hanzawaia, Bulimina, and Spiroplectammina spp.; Fig. 9), muddy fine sands with abundant shell fragments at the base are interpreted as the TST; the MFS is tentatively placed at $560 \mathrm{ft}(170.5 \mathrm{~m})$ based on a gamma-ray log peak and a secondary maximum in benthic foraminiferal abundances (Fig. 9). The lower HST silts are very poorly recovered (Figs. 8, 9). The upper HST consists of clean fine to medium sand with shells (563$535.8 \mathrm{ft}$ [171.6-163.4 m]) overlain by shelly clayey sand (535.8-510 $\mathrm{ft}$ [163.4-155.5 m]). The upper HST sands are interpreted as inner neritic based on the presence of $H$. cf. H. hughesi, Elphidium, and Nonionellina (Fig. 8, 9); these sands are overlain by clayey fine sands with interbeds of sandy clays $(510-506 \mathrm{ft}$ [155.5-154.3 m]) interpreted as prodelta. The transition from shelf below to prodelta above represents an shallowing-upward succession, although the facies fine upsection. 


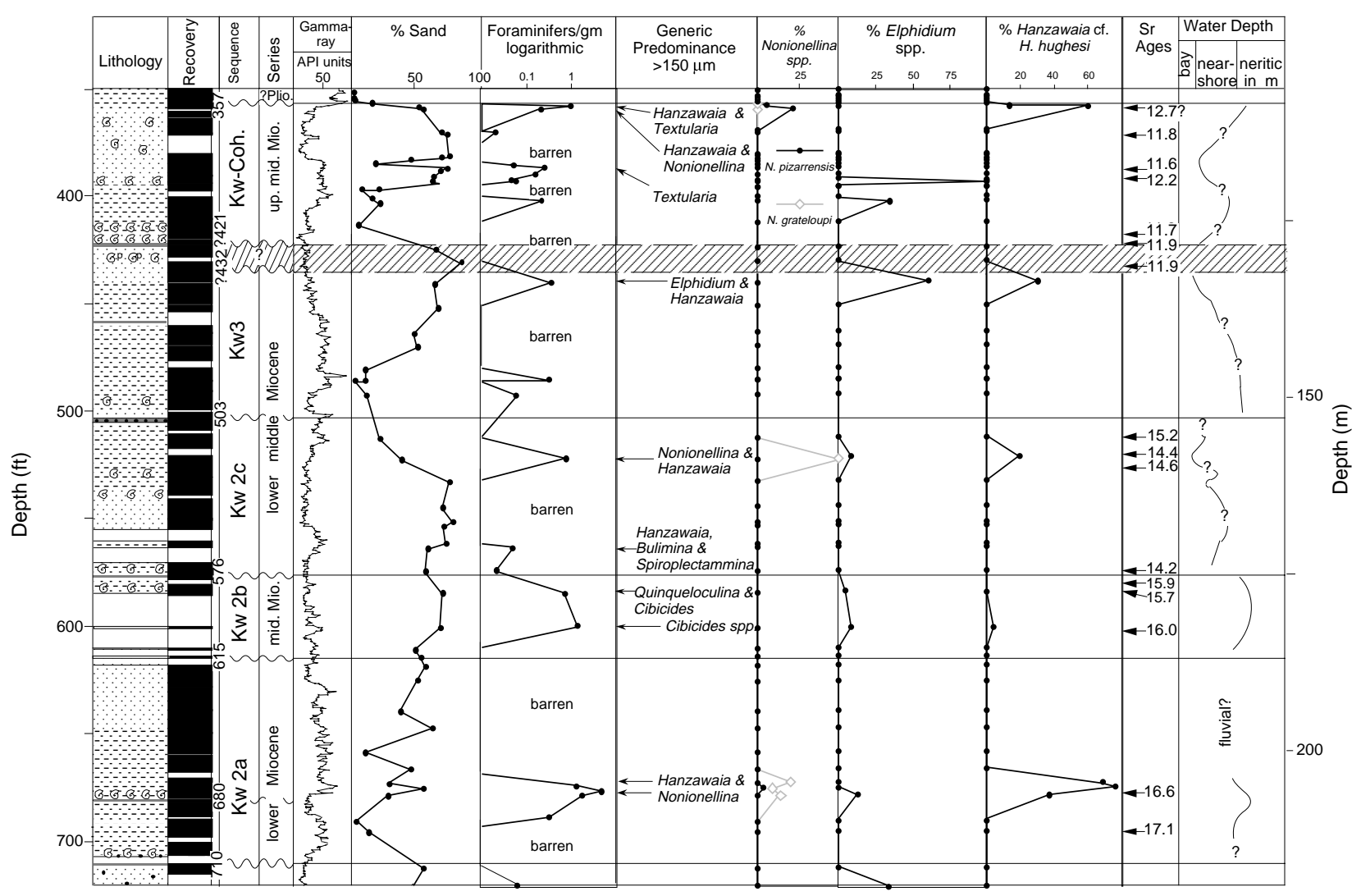

Figure 9. Benthic foraminiferal biofacies results, upper part of Cape May borehole. See Figure 2 caption for further explanation.

$K w 3$

At Cape May (Figs. 8, 9), the Kw3 sequence (503-432 ft [153.4$131.7 \mathrm{~m}]$ ) is a transgressive/regressive succession of basal shelly sands (TST), medial silts and clays (lower HST; 501.0-461.5 ft [152.8-140.7 m]), interbedded clay and clayey quartz fine sands (upper HST; 460-440.7 ft [140.2-134.4 m]), and sands $(440.7-432 \mathrm{ft}$ [134.4-131.7 m]). The MFS is placed at the top of the basal sands $(501 \mathrm{ft}[152.8 \mathrm{~m}])$, although it could be as high as $480 \mathrm{ft}(146.3 \mathrm{~m})$ based on peak abundances of foraminifers and a secondary gammaray log peak. The silts and clays were deposited in a prodelta or inner neritic environment based on the rare benthic foraminifers Bulimina and Hanzawaia. The HST sands were deposited in inner neritic to near-shore environments based on the presence of diatoms and foraminifers, including Elphidium.

At Atlantic City (Fig. 5), the Kw3 sequence (470-?370 ft [143.3$112.8 \mathrm{~m}]$ ) shallows but does not coarsen upward. In the lower part (450-470 ft [137.2-143.3 m]), burrowed, shelly silty clay and micaceous fine sand were deposited in inner neritic environments, representing the TST. The MFS is associated with the top of the silty clays. The section grades upward into laminated, shelly clay-silt and fine sand containing mica and carbonaceous material deposited in prodelta environments, representing the lower HST (450-435 ft [137.2$132.6 \mathrm{~m}])$. Above this, the beds become sandier to $425 \mathrm{ft}(129.6 \mathrm{~m})$. Clays at the top of the sequence (375-425 ft [114.3-129.6 m]) were interpreted as tidal flat (Sugarman and Miller, 1997). However, we note the presence of Nonionellina at $406 \mathrm{ft}(123.8 \mathrm{~m})$ and diatoms between samples at 399 and $421 \mathrm{ft}$ (121.6 and $128.4 \mathrm{~m}$ ), indicating marine (probably inner neritic prodelta environments) deposition. The upper contact of the sequence is inferred from the gamma-ray log, because the core was unrecovered in this interval.

\section{Kw-Cohansey}

The Kw-Cohansey sequence $(432-357 \mathrm{ft}$ [131.7-108.8 m]) is represented only at Cape May, where it coarsens upsection (Figs. 8, 9). At the base shelly fine-medium sand (432.2-418.4 ft [131.8$127.6 \mathrm{~m}])$ contains an indurated phosphatic fine sand (422.5-422.0 $\mathrm{ft}[128.8-128.6 \mathrm{~m}])$ and is overlain by a shell bed $(418.4-417.6 \mathrm{ft}$ [127.6-127.3 m]). The latter may mark the MFS, although a foraminiferal abundance peak is slightly above this ( 403 ft [122.9 m]; Figs. 8, 9). The lower HST is represented by a clay $(417-395.3 \mathrm{ft}$ [127.1-120.5 m]), while the upper HST is represented by medium shelly quartz sand $(395.3-357 \mathrm{ft}[120.5-108.8 \mathrm{~m}])$ with occasional thin laminated firm clays (e.g., $384.6-383.0 \mathrm{ft}[116.8-117.3 \mathrm{~m}]$ ). The basal shelly sands are near shore and lack foraminifers. Although the clays could be prodelta (Miller, et al., 1996a), the dominance of Elphidium indicates that they may be bay/lower estuarine. We interpret the upper HST sands as neritic-near shore; they contain diatoms and occasional inner neritic foraminifers (e.g., Textularia spp.; Figs. 8,9). A flooding surface occurs in the upper part of the sequence as indicated by the development of a Nonionellina-Hanzawaia $\mathrm{cf}$. $H$. hughesi biofacies, which is indicative of inner neritic environments (Figs. 8, 9).

\section{DISCUSSION}

\section{A Model for Miocene Sequences}

Miocene sequences appear to be relatively complete at our sites with TST basal sands, lower HST (silty clays), and upper HST (quartz sands) represented in all except Kw0 at Atlantic City and Kw2b at Atlantic City and Cape May. This contrasts with Oligocene 
sequences which are often truncated (Pekar et al., Chapter 15, this volume). We have observed no LSTs, and although TSTs are generally thin (typically less than 10-20 ft [3-6 m]), they are recognizable in the downdip boreholes as basal sandy zones (glauconite, shells, quartz sands). MFSs are often less clear, but are generally indicated by benthic foraminiferal abundance maxima, gamma-ray peaks, a facies transition from transgressive sands to regressive silty clays, and occasionally by indurated zones. Field studies were quite successful in identifying stratal surfaces, but only by subsequently integrating additional data ( $\mathrm{Sr}$-isotopic, benthic biofacies, and grain size) could unconformities be differentiated from MFSs. For example, the surface at $764 \mathrm{ft}(232.9 \mathrm{~m})$ at Cape May has many attributes of an unconformity (shell bed, indurated zone, facies change), but is now interpreted as a MFS within the Kw1c sequence (Fig. 6). Our studies confirm that the silty clays generally correspond to the lower HST, whereas medium to coarse quartz sands correspond to the upper HST (e.g., Fig. 6). The basal glauconite and shelly sands of the TST were deposited in inner to middle neritic environments. The silty clays of the lower HST were generally deposited in prodelta environments in inner neritic paleodepths, although delta-front environments are occasionally represented. The upper HST quartz sands were deposited in inner neritic, near-shore, delta-front, and fluvial environments.

The narrow paleodepth range of Miocene environments represented indicates that water depth variations associated with Miocene sequences were fairly low amplitude. Miocene sequences generally record $\sim 20-50 \mathrm{~m}$ of shallowing, which would correspond to less than $35 \mathrm{~m}$ of relative sea-level change (correcting for water loading alone). This is surprisingly low considering the large $(\sim 50-100 \mathrm{~m})$ glacioeustatic changes inferred from the $\delta^{18} \mathrm{O}$ record for this interval (Miller et al., 1991), but is similar to water-depth variation estimated for coeval sections in Maryland (Olsson et al., 1987). However, although we can constrain the amount of fall during the HST, we cannot estimate the full amplitude of relative sea-level falls because LSTs are not represented and the extent of subaerial exposure cannot be estimated. Haq et al. (1987) reported very high-amplitude eustatic changes for this interval ( $>100 \mathrm{~m})$; such large changes are not supported by $\delta^{18} \mathrm{O}$ variations, nor are they consistent with the rather low changes indicated for the portions of sequences preserved onshore in New Jersey and Maryland.

The long-term trends during the Miocene reflect a change from starved shelf, glauconite-dominated sedimentation to deltaic deposition during the early Miocene. The Kw0 sequence is composed primarily of recycled detrital glauconite to $\sim 22 \mathrm{Ma}$. By 21.4-21.6 Ma, a major change in sedimentation occurred. Glauconite became rare, except in the basal portions of sequences, and sedimentation rates increased from 5 to $22 \mathrm{~m} / \mathrm{m}$.y. during Kw0, to greater than $40 \mathrm{~m} / \mathrm{m}$.y after 21.6 Ma. This reflects not only a change in sediment supply but also a change in provenance; for example, the supply of coarser sediment increased in younger sequences, peaking in the latest middle Miocene Kw-Cohansey sequence (Fig. 8). Although the strong influence of deltaic sedimentation on Miocene sedimentation in New Jersey has been known for some time (e.g., Poag, 1978, 1985), we provide a precise age for the timing of this shift onshore: 22.2-21.4 Ma.

\section{Comparisons to Offshore Sequences}

Lower to middle Miocene sequences found beneath the continental shelf are thicker (often hundreds of meters per sequence) than their onshore counterparts. These sequences are seismically recognizable as prograding clinoforms with clear reflector terminations (Greenlee et al., 1988, 1992; Greenlee and Moore, 1988). These lower to middle Miocene clinoforms are primary targets for evaluating sequence stratigraphic models (e.g., Posamentier et al., 1988) and estimating amplitudes of relative sea-level change (e.g., using the methods of Greenlee et al., 1988). Lower to middle Miocene shelf reflectors were traced to the slope using a grid of multichannel seismic data collected by the R/V Ewing (Miller and Mountain, 1994). The reflectors and associated sequence boundaries were firmly correlated to the time scale using Sr-isotopic stratigraphy (Miller et al., 1996b), supplemented by planktonic foraminiferal (Snyder et al., 1996) and nannofossil (Aubry, 1996) biostratigraphy and magnetostratigraphy (Van Fossen and Urbat, 1996). These dates provide a chronology not only for the slope, but also for the correlative shelf sequences that can then be compared to coeval onshore sequences (Miller et al., 1996c). The ages of the sequence boundaries shown here for the onshore sites (Fig. 10) compare well with those offshore (Miller et al., 1996c; see fig. 3 in Miller, Chapter 1, this volume for comparison).

The facies of the sequences beneath the modern continental shelf are only indirectly known. Greenlee et al. (1992) summarized the results of oil drilling in the region. Most wells were washed through the Cenozoic section, although some excellent well logs were obtained. Using well logs, seismic profiles, and limited cutting samples, they provided a sequence stratigraphic interpretation of the offshore Miocene sequences, noting that they comprised predominantly HSTs. In contrast, Christie-Blick et al. (1992) interpreted these sequences as predominantly LSTs. ODP Leg 174A will begin to test these and other sequence stratigraphic interpretations of the offshore sequences by drilling two to three sites on the shelf.

Our studies onshore allow us to predict aspects of the offshore facies architecture. The Miocene was an interval of high sedimentation rates onshore, and extremely high ( $>100 \mathrm{~m} / \mathrm{m}$.y.) rates offshore. The sequences onshore preserve thick quartz sands in the HST, yet the lowstand deposits are absent onshore. Although much of the offshore sequence could be HST as predicted by Greenlee et al. (1992), it seems likely that substantial lowstand sands will be found beneath the modern shelf. The influence of deltaic sedimentation moved progressively offshore from 21 to $14 \mathrm{Ma}$, by which time it influenced the continental slope (Mountain, Miller, Blum, et al., 1994).

\section{Global vs. Tectonic Significance of Miocene Sequences}

We have previously discussed the relationship between Miocene sequences in New Jersey and the $\delta^{18} \mathrm{O}$ proxy of glacioeustasy, and have concluded that there is a very good correlation between the timing of sequence boundaries and glacioeustatic lowerings (Sugarman et al., 1993; Sugarman et al., Chapter 2, this volume; Miller and Sugarman, 1995; Miller et al., 1996c). Our comparison of the composite chronology for onshore sequences illustrates these correlations well (Fig. 10):

1. the Mi1 $\delta^{18} \mathrm{O}$ increase (inflection $23.8 \mathrm{Ma}$ ) correlates with a hiatus between $\mathrm{Kw} 0$ and Oligocene sequences;

2. the Mi1a $\delta^{18} \mathrm{O}$ increase (inflection $22.3 \mathrm{Ma}$ ) correlates with the hiatus between Kw0 and Kw1a;

3. the Mi1b $\delta^{18} \mathrm{O}$ increase (inflection $18.3 \mathrm{Ma}$ ) correlates with the hiatus between $\mathrm{Kw} 1 \mathrm{c}$ and $\mathrm{Kw} 2 \mathrm{a}$;

4. the $\mathrm{Mi} 2 \delta^{18} \mathrm{O}$ increase (inflection $16.3 \mathrm{Ma}$ ) correlates with the hiatus between $\mathrm{Kw} 2 \mathrm{a}$ and $\mathrm{Kw} 2 \mathrm{~b}$;

5. the Mi3a and Mi3b $\delta^{18} \mathrm{O}$ increases (inflections 13.6-14.4 Ma) correlate with the hiatus between $\mathrm{Kw} 2 \mathrm{c}$ and $\mathrm{Kw} 3$; and

6. the Mi4 $\delta^{18} \mathrm{O}$ increase (inflection $12.8 \mathrm{Ma}$ ) correlates with the hiatus between $\mathrm{Kw} 3$ and $\mathrm{Kw}-\mathrm{Cohansey.}$

Two onshore sequence boundaries (Kw1a/Kw1b and Kw1b/ $\mathrm{Kw} 1 \mathrm{c})$ are not associated with major $\delta^{18} \mathrm{O}$ increases. The regional significance of these sequence boundaries is unclear. As noted above, the $\mathrm{Kw} 1 \mathrm{a} / \mathrm{Kw} 1 \mathrm{~b}$ has no discernible hiatus, and it is possible that this boundary was not the result of a regional lowering of baselevel, but was due to an autocyclical facies change. The Kw1c has only been reported from the Cape May borehole, and its regional significance is uncertain. Nevertheless, it is interesting to note that these sequence boundaries may correlate with two smaller amplitude $\delta^{18} \mathrm{O}$ increases (indicated as Milaa and Milab on Fig. 10). 


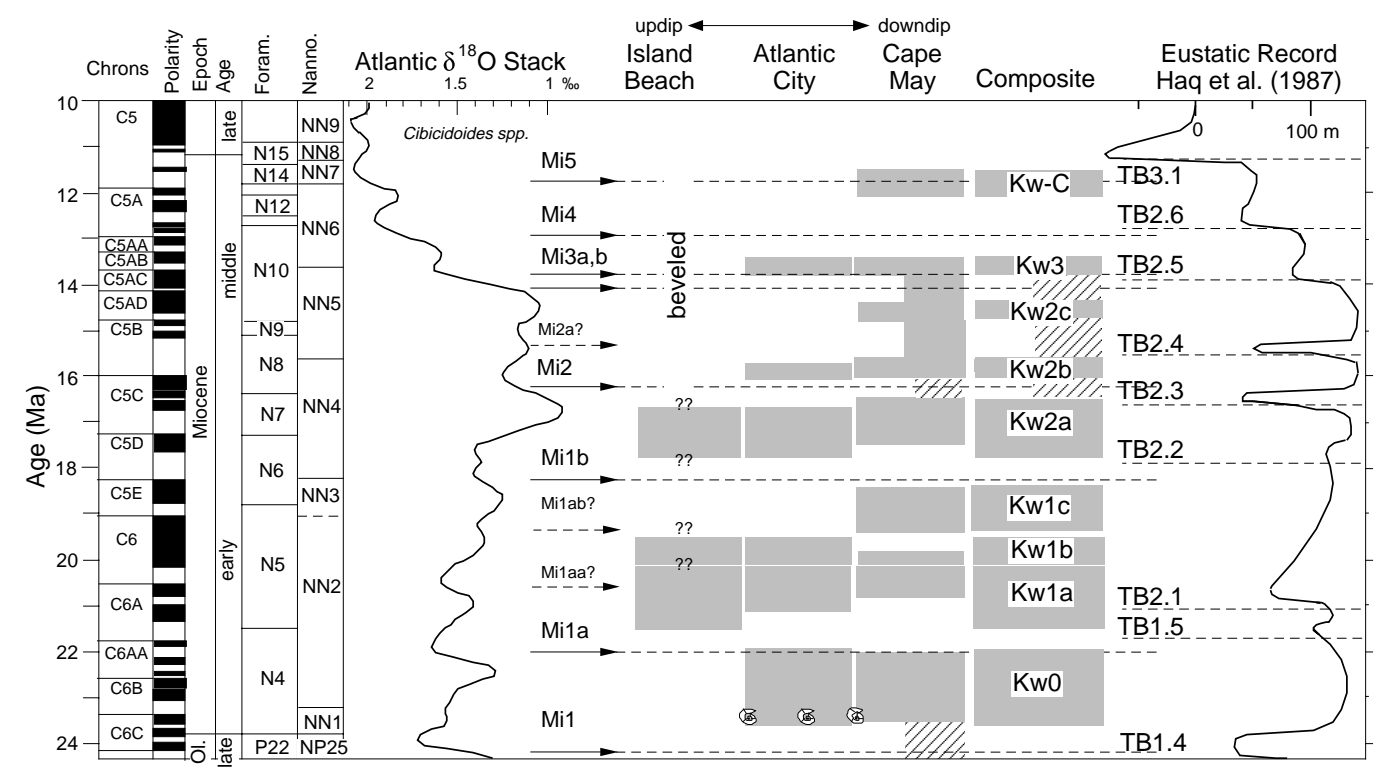

Fig. 10. Comparison of the stacked Atlantic benthic foraminiferal $\delta^{18} \mathrm{O}$ record (Wright and Miller, 1992) with the records of deposition at the three Leg $150 \mathrm{X}$ boreholes (stippled pattern indicates time represented, white areas indicate hiatuses, and cross-hatched pattern indicates uncertain age). Also shown is the inferred eustatic record of Haq et al. (1987). All records were converted to the Berggren et al. (1995) time scale. Mi1 through Mi5 are $\delta^{18} \mathrm{O}$ zones defined by maximum values; arrows are drawn at the inflection points in the oxygen-isotopic record prior to these maxima. Milaa?, Milab?, and Mi2a? are not formal zones but are indicated at minor $\delta^{18} \mathrm{O}$ changes. TB1.4 through TB3.1 are the sequence boundaries of Haq et al. (1987). Kw0 through Kw-C are sequences discussed here.

There is one disagreement between the $\delta^{18} \mathrm{O}$ and New Jersey Miocene records: the Mi15 increase correlates not with a hiatus, but with the $\mathrm{Kw}$-Cohansey sequence. This sequence has six Sr-isotopic age estimates that indicate an age of 11.6-12.2 Ma vs. an age of $11.7 \mathrm{Ma}$ for the $\delta^{18} \mathrm{O}$ increase. We attribute this discrepancy to two causes: (1) Sr-isotopic age resolution is lower in this interval; and (2) there are uncertainties and slight differences in the time scales used (i.e., the Oslick et al. (1994) Sr-age correlation used the CK92 time scale, whereas all other geological data have been calibrated to the BKSA95 time scale).

The excellent correlation between the ages of sequence boundaries and the oxygen-isotopic record establishes that eustasy was an important control on sedimentation on this margin. Our record also compares well with the Haq et al. (1987) synthesis: the bases of Kw0, $\mathrm{Kw} 1 \mathrm{a}, \mathrm{Kw} 2 \mathrm{a}, \mathrm{Kw} 2 \mathrm{~b}, \mathrm{Kw} 2 \mathrm{c}, \mathrm{Kw} 3$, and Kw-Cohansey correlate with their TB1.4, TB1.5/2.1, TB2.2, TB2.3, TB2.4, TB2.5, and TB2.6 sequence boundaries, respectively (Fig. 10). This reinforces our interpretation that eustasy was responsible for forming sequence boundaries on this margin.

All was not quiescent tectonically on this passive margin. The distribution of sequences reveals differential preservation attributable to tectonic effects. In general, additional sequences are preserved downdip, reflecting a gently hinging margin with increased subsidence downdip; for example, the Kw1c, Kw2c, and Kw-Cohansey sequences have only been found to date in New Jersey at Cape May (Fig. 10). There are exceptions to this pattern of better preservation of sequences downdip. As noted by Pekar et al. (Chapter 15, this volume), middle Oligocene sequences are present at Atlantic City, but are absent downdip; they attribute this to differential tectonic subsidence near Atlantic City due to sediment loading. In the Miocene (Fig. 10), the $\mathrm{Kw} 1 \mathrm{a}$ sequence is progressively well preserved (in both thickness and time) moving updip from Cape May to Island Beach. Similarly the Kw1b and Kw2a sequences are thicker updip. These differences result from differential subsidence on the order of tens of meters and probably reflect differences in basinal subsidence due to switching of depocenters from the north to the south. This is consistent with the general movement in the depocenter from New Jersey in the early Miocene to Maryland by the late middle to late Miocene (Owens et al., 1988).

Owens et al. (Chapter 2, this volume) termed the progressive shifting in basin depocenters the "rolling basin" concept. Although these differences can be explained by active tectonics (e.g., faulting of crustal blocks; e.g., Brown et al., 1972), we favor a more passive mechanism. Coastal plain accommodation is driven by flexural subsidence because of loading and thermal subsidence offshore (Watts, 1981). We suggest that increased sediment supply can also cause local flexural subsidence (see also Pazzaglia and Gardner, 1994). For example, early Miocene sedimentation rates increased in New Jersey as deltas prograded beneath the modern inner shelf (Greenlee et al., 1988), causing increased subsidence in the coastal plain. By the middle Miocene, deltas prograded beneath the middle shelf, and their loading and flexural effects were minimal on the New Jersey Coastal Plain. This, together with a long-term lowering of sea level, reduced accommodation by the late Miocene, resulting in non-marine deposition or hiatuses (Pazzaglia and Gardner, 1994). Thus, the fine-scale tectonic evolution of the basin is intricately tied to sediment supply.

If sediment supply affects the subsidence, then it could be argued that climate in the hinterland may be a substantial influence on the record. Sedimentation rates seemed to argue against this, because they were relatively uniform in the Miocene, remaining at $\sim 40 \mathrm{~m} /$ m.y. at both Atlantic City and Cape May after a depositional switch between Kw0 and Kw1a (22-21.4 Ma). The Cape May site may have had higher rates during Kwla and Kw1b (up to 90 m/m.y.). Nevertheless, the relative constancy argues against any major change in sediment supply after the depositional switch at 22-21.4 Ma. This occurred despite large changes in global climate during the Miocene (e.g., Miller et al., 1991).

One corollary to many depositional models is that sequences become more conformable downdip. We show here that this is not true on the fine scale (tens of meters), as Aubry (pers. comm., 1995) has shown that it is not true for Paleogene sequences on the New Jersey Margin. Rather, the interplay of eustasy, tectonics (including the ef- 
Table 1. Rotated loading values and cluster assignments for Cape May borehole samples.

\begin{tabular}{|c|c|c|c|c|c|c|c|c|}
\hline $\begin{array}{c}\text { Sample } \\
\text { depth } \\
\text { (ft) }\end{array}$ & $\begin{array}{c}\text { Sample } \\
\text { depth } \\
\text { (m) }\end{array}$ & $\begin{array}{c}\text { No. } \\
\text { specimens }\end{array}$ & Factor 1 & Factor 2 & Factor 3 & Factor 4 & Cluster & Biofacies \\
\hline 357.50 & 108.96 & 135 & 0.08 & -0.02 & 0.27 & 0.07 & $\mathrm{~d}$ & $?$ \\
\hline 358.80 & 109.36 & 10 & $?$ & $?$ & $?$ & $?$ & $\mathrm{c}$ & Hanzawaia \\
\hline 387.40 & 118.07 & 16 & $?$ & $?$ & $?$ & ? & $\mathrm{d}$ & ? \\
\hline 440.10 & 134.14 & 10 & $?$ & $?$ & $?$ & $?$ & $\mathrm{~d}$ & $?$ \\
\hline 522.10 & 159.13 & 26 & ? & $?$ & $?$ & $?$ & $\mathrm{a}$ & N. pizarrensis \\
\hline 584.00 & 177.99 & 22 & $?$ & $?$ & $?$ & $?$ & d & ? \\
\hline 600.10 & 182.90 & 52 & -0.04 & -0.04 & 0.15 & -0.01 & $\mathrm{~d}$ & $?$ \\
\hline 672.00 & 204.82 & 38 & $?$ & $?$ & $?$ & $?$ & $\mathrm{c}$ & Hanzawaia \\
\hline 675.10 & 205.76 & 99 & -0.01 & 0.08 & 0.96 & 0.17 & $\mathrm{c}$ & Hanzawaia \\
\hline 678.00 & 206.64 & 73 & -0.01 & 0.25 & 0.91 & 0.06 & $\mathrm{c}$ & Hanzawaia \\
\hline 752.00 & 229.20 & 10 & $?$ & $?$ & $?$ & $?$ & $\mathrm{c}$ & Hanzawaia \\
\hline 782.00 & 238.34 & 22 & $?$ & ? & ? & $?$ & $\mathrm{c}$ & Hanzawaia \\
\hline 822.10 & 250.56 & 55 & -0.06 & 0.01 & 0.19 & 0.38 & d & $?$ \\
\hline 837.10 & 255.14 & 66 & 0.54 & 0.62 & 0.25 & 0.49 & b & N. pizarrensis/Bulimina \\
\hline 880.00 & 268.21 & 116 & 0.03 & 0.18 & 0.21 & 0.94 & $\mathrm{e}$ & N. grateloupi \\
\hline 890.10 & 271.29 & 12 & $?$ & $?$ & $?$ & $?$ & a & N. pizarrensis \\
\hline 911.10 & 277.69 & 16 & $?$ & $?$ & $?$ & $?$ & $\mathrm{e}$ & N. grateloupi \\
\hline 945.00 & 288.02 & 252 & 0.17 & -0.02 & 0.94 & 0.21 & $\mathrm{c}$ & Hanzawaia \\
\hline 967.10 & 294.76 & 16 & $?$ & $?$ & $?$ & $?$ & $\mathrm{~b}$ & Bulimina \\
\hline 972.00 & 296.25 & 112 & 0.84 & 0.07 & 0.24 & 0.44 & $\mathrm{~b}$ & Bulimina \\
\hline 979.00 & 298.38 & 135 & 0.61 & 0.11 & -0.02 & 0.57 & $\mathrm{~b}$ & Bulimina/N. grateloupi \\
\hline 1000.10 & 304.82 & 98 & 0.69 & 0.48 & 0.04 & 0.48 & $\mathrm{~b}$ & Bulimina \\
\hline 1004.90 & 306.28 & 264 & 0.41 & 0.28 & -0.11 & 0.85 & $\mathrm{e}$ & N. grateloupi \\
\hline 1011.10 & 308.17 & 272 & 0.11 & 0.18 & 0.26 & 0.93 & $\mathrm{e}$ & N. grateloupi \\
\hline 1014.70 & 309.27 & 933 & 0.08 & 0.85 & -0.07 & 0.49 & $\mathrm{a}$ & N. pizarrensis \\
\hline 1020.10 & 310.91 & 342 & 0.14 & 0.24 & 0.20 & 0.93 & $\mathrm{e}$ & N. grateloupi \\
\hline 1022.00 & 311.49 & 360 & 0.02 & 0.97 & 0.09 & -0.01 & $\mathrm{a}$ & N. pizarrensis \\
\hline 1032.10 & 314.57 & 353 & 0.01 & 0.97 & -0.01 & 0.23 & $\mathrm{a}$ & N. pizarrensis \\
\hline 1035.10 & 315.48 & 158 & 0.00 & 0.97 & 0.00 & 0.19 & $\mathrm{a}$ & N. pizarrensis \\
\hline 1040.10 & 317.01 & 352 & -0.02 & 0.98 & 0.02 & -0.03 & a & N. pizarrensis \\
\hline 1045.10 & 318.53 & 254 & 0.57 & 0.65 & -0.03 & 0.13 & a & N. pizarrensis/Bulimina \\
\hline 1045.20 & 318.56 & 298 & 0.32 & 0.82 & -0.06 & 0.44 & $\mathrm{a}$ & N. pizarrensis \\
\hline 1050.00 & 320.02 & 141 & 0.96 & 0.05 & -0.01 & 0.07 & $\mathrm{~b}$ & Bulimina \\
\hline 1050.10 & 320.05 & 169 & 0.98 & 0.04 & -0.01 & 0.06 & $\mathrm{~b}$ & Bulimina \\
\hline 1058.00 & 322.46 & 11 & $?$ & $?$ & $?$ & $?$ & $\mathrm{e}$ & $N$. grateloupi \\
\hline 1062.00 & 323.68 & 46 & ? & ? & ? & ? & $\mathrm{e}$ & N. grateloupi \\
\hline 1066.80 & 325.14 & 45 & ? & ? & ? & ? & $\mathrm{b}$ & Bulimina \\
\hline 1068.40 & 325.63 & 78 & 0.39 & 0.19 & -0.14 & 0.86 & $\mathrm{e}$ & N. grateloupi \\
\hline 1120.10 & 341.39 & 10 & $?$ & $?$ & $?$ & $?$ & d & ? \\
\hline 1130.10 & 344.44 & 21 & $?$ & $?$ & $?$ & $?$ & d & $\dot{q}$ \\
\hline 1162.10 & 354.19 & 67 & 0.90 & -0.03 & 0.02 & -0.02 & $\mathrm{~b}$ & Bulimina \\
\hline
\end{tabular}

Note: ? = samples were not included in factor analysis.

fects of simple thermal subsidence, flexure, compaction, and loading), and sediment supply results in more complex depositional patterns. The Miocene shows a relatively simple pattern (Fig. 10), yet it still records basinal differences. Although Atlantic City and Cape May project downdip of Island Beach (Fig. 1), they are also offset along strike, allowing us to sample sequences that are absent in the region of Island Beach due to localized erosion (Owens et al., 1995). This emphasizes a major point: to understand controls on the depositional record, transects must be drilled not only along dip transects, but also along strike to sample the full mosaic of sequences and to understand the role of tectonics.

\section{CONCLUSION}

Nine lower to middle Miocene sequences of the Kirkwood Formation are recorded at the Leg 150X boreholes: Kw0, Kw1a, Kw1b, $\mathrm{Kw} 1 \mathrm{c}, \mathrm{Kw} 2 \mathrm{a}, \mathrm{Kw} 2 \mathrm{~b}, \mathrm{Kw} 2 \mathrm{c}, \mathrm{Kw} 3$, and Kw-Cohansey. The sequence boundaries not only correlate well with offshore sequence boundaries and those of Haq et al. (1987), but also match global $\delta^{18} \mathrm{O}$ increases (inferred glacioeustatic lowerings). This confirms the primary role of eustasy in controlling the formation of Miocene sequence boundaries on this passive margin.

We used lithofacies, well-log, and benthic foraminiferal biofacies data to interpret paleoenvironmental changes and to identify Systems Tracts within the sequences. Miocene sequences were deposited in middle neritic (30-100 m), inner neritic $(0-30 \mathrm{~m})$, near-shore, bay/ lower estuarine, and fluvial environments. Lowermost Miocene sequence Kw0 was deposited under open-shelf conditions, whereas subsequent sequences were deposited under deltaic influences and include prodelta and delta-front subenvironments. Sequences comprise transgressive/regressive packages, with lower sands (TST), medial silty clays (lower HST), and upper prograding quartz sands (upper HST). Sequences become progressively shallower from the early to the middle Miocene, reflecting reduced accommodation from offshore migration of depocenters and long-term sea-level lowering. Minor tectonic differences (tens of meters) caused by along-strike migration of depocenters resulted in differential preservation of sequences. We conclude that both dip and strike transects of margins are needed to unravel the interwoven effects of eustasy, tectonics, and sediment supply.

\section{ACKNOWLEDGMENTS}

The benthic foraminiferal biofacies studies presented here were pioneered by R.K. Olsson, and the lithofacies models were first proposed by the late J. Owens and colleagues. We thank them for leading the way. We thank R.K. Olsson for discussions, and S.W. Snyder and L. Ward for reviews. Supported by NSF Grants EAR92-18210 and EAR94-17108. This is LDEO contribution 5678.

\section{REFERENCES}

Andrews, G.W., 1988. A revised marine diatom zonation for Miocene strata of the southeastern United States. Geol. Surv. Prof. Pap. U.S., 1481:1-29. Aubry, M.-P., 1996. Data Report: Eocene to upper Miocene calcareous nannofossil stratigraphy. In Mountain, G.S., Miller, K.G., Blum, P., Poag, 
C.W., and Twichell, D.C. (Eds.), Proc. ODP, Sci. Results, 150: College Station, TX (Ocean Drilling Program), 435-437.

Bandy, O.L., and Arnal, R.E., 1957. Distribution of Recent foraminifera off the west coast of Central America. AAPG Bull., 41:2037-2053.

Berggren, W.A., Kent, D.V., Flynn, J.J., and van Couvering, J.A., 1985. Cenozoic geochronology. Geol. Soc. Am. Bull., 96:1407-1418.

Berggren, W.A., Kent, D.V., Swisher, C.C., III, and Aubry, M.-P., 1995. A revised Cenozoic geochronology and chronostratigraphy. In Berggren, W.A., Kent, D.V., Aubry, M.-P., and Hardenbol, J. (Eds.), Geochronology, Time Scales and Global Stratigraphic Correlation. Spec. Publ.Soc. Econ. Paleontol. Mineral., 54:129-212.

Boersma, A., 1984. A Handbook of Common Tertiary Uvigerina: Stony Point, NY (Microclimates Press).

Brown, P.M., Miller, J.A., and Swain, F.M., 1972. Structural and stratigraphic framework, and spatial distribution of permeability of the Atlantic Coastal Plain, North Carolina to New York. Geol. Surv. Prof. Pap. U.S., 796:1-79.

Butt, A.A., 1966. Late Oligocene Foraminifera from Escornebeou, SW France: Utrecht (Schotanus and Jens).

Cande, S.C., and Kent, D.V., 1992. A new geomagnetic polarity time scale for the Late Cretaceous and Cenozoic. J. Geophys. Res., 97:1391713951.

Christie-Blick, N., Miller, K.G., Mountain, G.S., Driscoll, N.W., Reynolds, D.J., and Steckler, M.S., 1992. Sequence stratigraphy and sea-level change: examples from the Atlantic margins of the U.S. and Canada, The Tectonics, Sedimentation and Palaeoceanography of the North Atlantic Region, Edinburg (Geol. Soc. London).

Cushman, J.A. and Cahill, E.D., 1933. Miocene Foraminifera of the coastal plain of the eastern U.S. Geol. Surv. Prof. Pap. U.S., 175A.

Cushman, J.A., and Stainforth, R.M., 1945. The foraminifera of the Cipero Marl Formation of Trinidad, British West Indies. Spec. Publ.-Cushman Lab., 14:1-75.

Gibson, T.G., 1971. Miocene of the middle Atlantic Coastal Plain. In Gernant, R.E., Gibson, T.G., and Whitmore, F.C.J. (Eds.), Environmental History of Maryland Miocene: Baltimore (Maryland Geol. Surv.), 1-15.

Greenlee, S.M., Devlin, W.J., Miller, K.G., Mountain, G.S., and Flemings, P.B., 1992. Integrated sequence stratigraphy of Neogene deposits, New Jersey continental shelf and slope: comparison with the Exxon model. Geol. Soc. Am. Bull., 104:1403-1411.

Greenlee, S.M., and Moore, T.C., 1988. Recognition and interpretation of depositional sequences and calculation of sea level changes from stratigraphic data-offshore New Jersey and Alabama Tertiary. In Wilgus, C.K., Hastings, B.S., Kendall, C.G.St.C., Posamentier, H.W., Ross, C.A., and Van Wagoner, J.C. (Eds.), Sea Level Changes: An Integrated Approach. Spec. Publ.-Soc. Econ. Paleontol. Mineral., 42:329-353.

Greenlee, S.M., Schroeder, F.W., and Vail, P.R., 1988. Seismic stratigraphic and geohistory analysis of Tertiary strata from the continental shelf off New Jersey: calculation of eustatic fluctuations from stratigraphic data. In Sheridan, R.E., and Grow, J.A. (Eds.), The Atlantic Continental Margin. Geol. Soc. Am., Geol. North Am. Ser., 437-444.

Haq, B.U., Hardenbol, J., and Vail, P.R., 1987. Chronology of fluctuating sea levels since the Triassic. Science, 235:1156-1167.

Hart, S.R., and Brooks, C., 1974. Clinopyroxene-matrix partitioning of K, $\mathrm{Rb}, \mathrm{Cs}$, and Ba. Geochem. Cosmochim. Acta, 38:1799-1806.

Isphording, W.C., 1970. Petrology, stratigraphy, and re-definition of the Kirkwood Formation (Miocene) of New Jersey. J. Sediment. Petrol., 40:986-997.

Knapp, G.N., 1904. Underground waters of New Jersey, Part IV. Annu. Rep. State Geologist 1903, Geol. Surv. New Jersey, 73-93.

Loeblich, A.R., and Tappan, H., 1964. Sarcodina. In Moore, R.C. (Ed.) Treatise on Invertebrate Paleontology, Pt. C, Protista 2 (vols. 1 and 2): Boulder (Geol. Soc. Am. and Univ. Kansas Press).

Loeblich, A.R., Jr., and Tappan, H., 1988. Foraminiferal Genera and Their Classification: New York (Van Nostrand Reinhold).

Loutit, T.S., Hardenbol, J., Vail, P.R. and Baum, G.R., 1988. Condensed sections: the key to age determination and correlation of continental margin sequences. In Wilgus, C.K., Hastings, B.S., Ross, C.A., Posamentier, H.W., Van Wagoner, J., and Kendall, C.G.St.C. (Eds.), Sea-Level Changes: An Integrated Approach. Spec. Publ.-Soc. Econ. Paleontol. Mineral., 42:183-213.

McRae, S.G., 1972. Glauconite. Earth-Sci. Rev., 8:397-440.
Miller, K.G., et al., 1994. Proc. ODP, Init. Repts., 150X: College Station, TX (Ocean Drilling Program).

_, 1996a. Proc. ODP, Init. Repts., 150X (Suppl.): College Station, TX (Ocean Drilling Program).

Miller, K.G., Aubry, M.-P., Khan, K.J., Melillo, A.J., Kent, D.V., and Berggren, W.A., 1985. Oligocene-Miocene biostratigraphy, magnetostratigraphy and isotopic stratigraphy of the western North Atlantic. Geology, 13:257-261.

Miller, K.G., Kent, D.V., Brower, A.N., Bybell, L.M., Feigenson, M.D., Olsson, R.K., and Poore, R.Z., 1990. Eocene-Oligocene sea-level changes on the New Jersey coastal plain linked to the deep-sea record. Geol. Soc. Am. Bull., 102:331-339.

Miller, K.G., Liu, C., and Feigenson, M.D., 1996b. Oligocene to middle Miocene Sr-isotopic stratigraphy of the New Jersey continental slope. In Mountain, G.S., Miller, K.G., Blum, P., Poag, C.W., and Twichell, D.C. (Eds.), Proc. ODP, Sci. Results, 150: College Station, TX (Ocean Drilling Program), 97-114.

Miller, K.G., and Lohmann, G.P., 1982. Environmental distribution of Recent benthic foraminifera on the northeast United States continental slope. Geol. Soc. Am. Bull., 93:200-206.

Miller, K.G., and Mountain, G.S., 1994. Global sea-level change and the New Jersey margin. In Mountain, G.S., Miller, K.G., Blum, P., et al., Proc. ODP, Init. Repts., 150: College Station, TX (Ocean Drilling Program), $11-20$.

Miller, K.G., Mountain, G.S., Blum, P., Gartner, S., Alm Per, G., Aubry, M.P., Burckle, L.H., Guerin, G., Katz, M.E., Christensen, B.A., Compton, J., Damuth, J.E., Deconinck, J.F., de Verteuil, L., Fulthorpe, C.S., Hesselbo, S.P., Hoppie, B.W., Kotake, N., Lorenzo, J.M., McCracken, S., McHugh, C.M., Quayle, W.C., Saito, Y., Snyder, S.W., ten Kate, W.G., Urbat, M., Van Fossen, M.C., Vecsei, A., Sugarman, P.J., Mullikin, L., Pekar, S., Browning, J.V., Liu, C., Feigenson, M.D., Goss, M., Gwynn, D., Queen, D.G., Powars, D.S., Heibel, T.D., and Bukry, D., 1996. Drilling and dating New Jersey Oligocene-Miocene sequences: ice volume, global sea level, and Exxon records. Science, 271:1092-1095.

Miller, K.G., and Sugarman, P.J., 1995. Correlating Miocene sequences in onshore New Jersey boreholes (ODP Leg 150X) with global $\delta^{18} \mathrm{O}$ and Maryland outcrops. Geology, 23:747-750.

Miller, K.G., Wright, J.D., and Fairbanks, R.G., 1991. Unlocking the Ice House: Oligocene-Miocene oxygen isotopes, eustasy, and margin erosion. J. Geophys. Res., 96:6829-6848.

Mountain, G.S., Miller, K.G., Blum, P., et al., 1994. Proc. ODP, Init. Repts., 150: College Station, TX (Ocean Drilling Program).

Murray, J.W., 1991. Ecology and Palaeoecology of Benthic Foraminifera: New York (Wiley and Sons Inc.).

North American Commission on Stratigraphic Nomenclature, 1983. North American Stratigraphic Code. AAPG Bull., 67:841-875.

Olsson, R.K., Melillo, A.J., and Schreiber, B.L., 1987. Miocene sea level events in the Maryland Coastal Plain and the offshore Baltimore Canyon Trough. In Ross, C., and Haman, D. (Eds.), Timing and Depositional History of Eustatic Sequences: Constraints on Seismic Stratigraphy. Spec. Publ. Cushman Found. Foraminiferal Res., 24:85-97.

Oslick, J.S., Miller, K.G., and Feigenson, M.D., 1994. Oligocene-Miocene strontium isotopes: stratigraphic revisions and correlations to an inferred glacioeustatic record. Paleoceanography, 9:427-423.

Owens, J.P., Bybell, L.M., Paulachok, G., Ager, T.A., Gonzalez, V.M., and Sugarman, P.J., 1988. Stratigraphy of the Tertiary sediments in a 945foot-deep core hole near Mays Landing in the southeastern New Jersey Coastal Plain. Geol. Surv. Prof. Pap. U.S., 1484.

Owens, J.P., and Gohn, G.S., 1985. Depositional history of the Cretaceous series in the U.S. coastal plain: stratigraphy, paleoenvironments, and tectonic controls of sedimentation. In Poag, C.W. (Ed.), Geologic Evolution of the United States Atlantic Margin: New York (Van Nostrand Reinhold), 25-86.

Owens, J.P., and Sohl, N.F., 1969. Shelf and deltaic paleoenvironments in the Cretaceous-Tertiary formations of the New Jersey Coastal Plain. In Subitzky, S. (Ed.), Geology of Selected Areas in New Jersey and Eastern Pennsylvania and Guidebook of Excursions: New Brunswick, NJ (Rutgers Univ. Press), 235-278.

Owens, J.P., Sugarman, P.J., Sohl, N.F., Parker, R., Houghton, H.H., Volkert, R.V., Drake, A.A., and Orndorff, R.C., 1995. Geologic map of New Jersey: Central Sheet. Open-File Rep.-U.S. Geol. Surv., 95-253. 
Pazzaglia, F.J., and Gardner, T.W., 1994. Late Cenozoic flexural deformation of the middle U. S. Atlantic passive margin. J. Geophys. Res., 99:1214312157.

Poag, C.W., 1978. Stratigraphy of the Atlantic continental shelf and slope of the United States. Annu. Rev. Earth Planet. Sci., 6:251-280. 1981. Ecologic Atlas of Benthic Foraminifera of the Gulf of Mexico: Woods Hole (Marine Science International).

, 1985. Depositional history and stratigraphic reference section for central Baltimore Canyon trough. In Poag, C.W. (Ed.), Geologic Evolution of the United States Atlantic Margin: New York (Van Nostrand Reinhold), 217-263.

Poore, R.Z., and Bybell, L.M., 1988. Eocene to Miocene biostratigraphy of New Jersey core ACGS \#4: Implications for regional stratigraphy. Geol. Surv. Prof. Pap. U.S., 1829.

Posamentier, H.W., Jervey, M.T., and Vail, P.R., 1988. Eustatic controls on clastic deposition, I. Conceptual framework. In Wilgus, C.K., Hastings, B.S., Ross, C.A., Posamentier, H.W., Van Wagoner, J., and Kendall, C.G.St.C. (Eds.), Sea-Level Changes: An Integrated Approach. Spec. Publ.-Soc. Econ. Paleontol. Mineral., 42:109-124.

Schnitker, D., 1970. Upper Miocene Foraminifera From Near Grimeland, Pitt County, North Carolina. North Carolina Dept. Conservation and Development.

1971. Distribution of foraminifera on the North Carolina Continental Shelf. Tulane Stud. Geol. Paleont., 8:169-215.

Sen Gupta, B.K., and Kilborne, R.T., 1976. Depth distribution of benthic foraminifera on the Georgia continental shelf. Maritime Sed., 1:25-38.

Smith, P.B., 1964. Ecology of benthonic species. Geol. Surv. Prof. Pap. U.S., 429-B.

Snyder, S.W., Miller, K.G., and Saperson, E., 1996. Paleogene and Neogene planktonic foraminiferal biostratigraphy of the New Jersey continental slope: Site 902, 903, and 904 (Leg 150). In Mountain, G.S., Miller, K.G., Blum, P., Poag, C.W., and Twichell, D.C. (Eds.), Proc. ODP, Sci. Results, 150: College Station, TX (Ocean Drilling Program), 3-15.

Snyder, S.W., Waters, V.J., and Moore, T.L., 1988. Benthic foraminifera and paleoecology of Miocene Pungo River Formation sediments in Onslow Bay, North Carolina continental shelf. In Snyder, S.W. (Ed.), Micropaleontology of Miocene Sediments in the Shallow Subsurface of Onslow Bay, North Carolina Continental Shelf. Spec. Publ. Cushman Found. Foraminiferal Res., 25:43-96.

Sugarman, P.J., and Miller, K.G., 1997. Correlation of Miocene global sequences and hydrostratigraphic units, New Jersey coastal plain. Sediment. Geol., 108:3-18.

Sugarman, P.J., Miller, K.G., Bukry, D., Feigenson, M.D., 1995. Uppermost Campanian-Maestrichtian strontium isotopic, biostratigraphic, and sequence stratigraphic framework of the New Jersey Coastal Plain. Geol. Soc. Am. Bull., 107:19-37.

Sugarman, P.J., Miller, K.G., Owens, J.P., and Feigenson, M.D., 1993. Strontium isotope and sequence stratigraphy of the Miocene Kirkwood Formation, Southern New Jersey. Geol. Soc. Am. Bull., 105:423-436.

Van Fossen, M.C., and Urbat, M., 1996. Magnetostratigraphy of Miocene and Pleistocene sediments on the New Jersey slope. In Mountain, G.S., Miller, K.G., Blum, P., Poag, C.W., and Twichell, D.C. (Eds.), Proc. ODP, Sci. Results, 150: College Station, TX (Ocean Drilling Program), 129-143.

Van Morkhoven, F.P.C.M., Berggren, W.A., and Edwards, A.S., 1986. Cenozoic Cosmopolitan Deep-Water Benthic Foraminifera. Bull. Cent. Rech. Explor-Prod. Elf-Aquitaine, Mem. 11.

Van Wagoner, J.C., Posamentier, H.W., Mitchum, R.M., Jr., Vail, P.R., Sarg, J.F., Loutit, T.S., and Hardenbol, J., 1988. An overview of the fundamentals of sequence stratigraphy and key definitions. In Wilgus, C.K., Hastings, B.S., Ross, C.A., Posamentier, H.W., Van Wagoner, J., and Kendall, C.G.St.C. (Eds.), Sea-Level Changes: An Integrated Approach. Spec. Publ.-Soc. Econ. Paleontol. Mineral., 42:39-45.

Walton, W.R., 1964. Recent foraminiferal ecology and paleoecology. In Imbrie, J., and Newell, N.D. (Eds.), Approaches to Paleoecology: New York (Wiley), 151-237.

Watts, A.B., 1981. The U.S. Atlantic continental margin: subsidence history, crustal structure and thermal evolution, In Bally, A.W., Watts, A.B., Grow, J.A., Manspeizer, W., Bernoulli, D., Schreiber, C., and Hunt, J.M. (Eds.), Geology of Passive Continental Margins, AAPG Short Course Notes, 19:2/1-2/75.

Woolman, L., 1898. Artesian wells in New Jersey, Pt. IV. Annu. Rep. State Geol. 1897, Geolog. Surv. New Jersey, 211-295.

Wright, J.D., and Miller, K.G., 1992. Miocene stable isotope stratigraphy, Site 747, Kerguelen Plateau. In Wise, S.W., Jr., Schlich, R., et al., Proc. ODP, Sci. Results, 120: College Station, TX (Ocean Drilling Program), 855-866.

Zapecza, O., 1989. Hydrogeologic framework of the New Jersey Coastal Plain. Geol. Surv. Prof. Pap. U.S., 1404-B.

Date of initial receipt: 11 March 1996

Date of acceptance: 19 August 1996

Ms 150XSR-313 


\section{APPENDIX}

\section{Revised Definition of the Lower to Middle Miocene Kirkwood Formation, New Jersey Coastal Plain}

In outcrop and in the subsurface, the unconsolidated sands, silts, and clays of the lower to middle Miocene Kirkwood Formation are unconformably overlain by the Miocene Cohansey Formation, and unconformably overlie Oligocene or older sediments. The Kirkwood Formation was named for outcrops near Kirkwood, Camden County, NJ (Knapp, 1904). The outcropping Kirkwood was subdivided into three members (Isphording, 1970): (1) Asbury Park Member, a restricted facies deposited in lagoons, swamps, and estuaries; (2) Grenloch Sand, a neritic to near-shore sand; and (3) Alloway Clay, a largely prodelta deposit. The spatial and temporal relationships of these members to each other are not discernible due to poor outcrops, rapidly varying facies, and poor age control on outcrops

Based on outcrop and detailed subsurface studies of the ACGS\#4 borehole (Fig. 1), Andrews (1988) identified three of his East Coast Diatom Zones (ECDZ) in the Kirkwood Formation: ECDZ 1, ECDZ 2, and ECDZ 6. Sugarman et al. (1993) recognized that these zones correspond to three sequences within the Kirkwood Formation (Kw1, Kw2, and Kw3), and that the Kw1 and Kw2 could be further subdivided into Kw1a-Kw1b and Kw2a-Kw2b sequences, respectively. By integrating sequence and $\mathrm{Sr}$-isotopic studies of the Kirkwood Formation, Sugarman et al. (1993) were able to recognize, date, and map these five $\mathrm{Kw}$ sequences in the subsurface of the New Jersey Coastal Plain.

Owens et al. (1995) recently suggested redefining the Kirkwood Formation. They recognized four formations increasing in age: Belleplain, Wildwood, Shiloh Marl, and Kirkwood. These lithostratigraphic units are equivalent to the $\mathrm{Kw} 3, \mathrm{Kw} 2 \mathrm{a}$ and $\mathrm{Kw} 2 \mathrm{~b}, \mathrm{Kw} 1 \mathrm{~b}$, and $\mathrm{Kw} 1 \mathrm{a}$ and $\mathrm{Kw} 0$ sequences, respectively, of Sugarman et al. (1993), Miller and Sugarman (1995), and this report. In this paper, we retain the older use of the Kirkwood Formation and apply Owens et al.'s (1995) terminology as members of the Kirkwood Formation (Fig. 5). We do this as a stratigraphically conservative measure: although these lithostratigraphic units are readily differentiated and mapped downdip in our boreholes, at outcrop and updip wells it is often difficult to differentiate among these units. In addition, maintaining the broader sense of the Kirkwood Formation is consistent with existing hydrogeologic nomenclature (Zapecza, 1989) and with our sequence stratigraphic nomenclature (e.g., Kw1-3). We thus maintain the Kirkwood as a formation mappable throughout the coastal plain, and assign its subdivisions to member status. This follows the North American Commission on Stratigraphic Nomenclature (1983), "Even if all members of a formation are locally mappable, it does not follow that they should be raised to formational rank, because proliferation of formation names may obscure rather than clarify relations with other areas." In our case, raising the members to formational status would obscure relationships updip and at outcrop where the members are not readily differentiable.

We name the most widespread unit the Brigantine Member; this corresponds to the Kw0 and Kw1a sequences of the Kirkwood Formation in the restricted sense of Owens et al. (1995). We follow Owens et al. (1995) in their descriptions of the lithology, age, and stratigraphic boundaries of the overlying Shiloh Marl, Wildwood, and Belleplain Members of the Kirkwood Formation (Fig. 5) and provide a formal designation of the Brigantine Member here.

\section{Brigantine Member}

We formally designate lower lower Miocene sands and clays between 914.4 and $741 \mathrm{ft}$ (278.8 and 225.9 m) at the Atlantic City (Leg 150X) borehole the Brigantine Member (Fig. 5). This unit has long been recognized as a distinct lithologic unit at Atlantic City. For example Woolman (1898) recognized the "800-foot Atlantic City horizon" that is part of this member, and this unit is an important aquifer for the city of Atlantic City (Zapecza, 1989). The name is derived from the adjacent town of Brigantine, NJ, which is located $1.2 \mathrm{~km}$ across Absecon Inlet from the stratotype borehole. The name Atlantic City Formation is used for the underlying Oligocene glauconite sands that are also stratotypified at this borehole (Fig. 5; Pekar et al., Chapter 8, this volume), whereas the Absecon Inlet Formation is used for the upper Eocene at this borehole (Browning et al., Chapter 18, this volume).

The Brigantine Member has a shell bed and glauconite sand at its base, a medial dark gray to massive to thin bedded clay to clay silt, and an upper quartz sand. Detailed lithostratigraphic descriptions are provided by Miller, et al. (1994), Owens et al. (1995), and this paper. The lower boundary at the type section is marked by a gamma-ray log maximum (Fig. 5) and the base of a shell bed; it corresponds to the $914.4 \mathrm{ft}(278.8 \mathrm{~m})$ disconformity. The upper contact separates homogeneous medium to coarse quartz sands with occasional organic-rich layers below from shelly firm silty clay and clayey sands above; this contact is marked by a large gamma-ray log kick and is a major disconformity (741 ft [225.9 m]; Fig. 5). Thus, in addition to its lithostratigraphic significance, the Brigantine Member is an unconformity bounded unit (Fig. 5), as allowed by the North American Commission on Stratigraphic Nomenclature (1983)

In the subsurface, the Kw1a and Kwlb have been mapped as the lower Kirkwood Formation by Sugarman et al. (1993; their fig. 3b), where it reaches maximum thickness between Atlantic City and Island Beach. The member is $205 \mathrm{ft}(62.5 \mathrm{~m}), 172 \mathrm{ft}(52.4 \mathrm{~m})$, and $238 \mathrm{ft}(72.6 \mathrm{~m})$ at Island Beach, Atlantic City, and Cape May, respectively. At the ACGS\#4 borehole, it is $104 \mathrm{ft}$ thick $(31.7 \mathrm{~m})$. Sugarman and Miller (1997) present a dip cross section from Zee Orchards to Atlantic City (Sugarman and Miller, 1997, fig. 6) that documents the updip thinning of this member and shows that the upper sands are truncated updip between the ACGS\#4 borehole and Buena. The cross sections also show that the upbasin thickening from Atlantic City to Island Beach is caused by thickening of the upper sands in an oblique strike section (Sugarman and Miller, 1997, fig. 5). At Atlantic City, the composite confining bed of Zapecza (1989) is composed of the Kw0 sequence and the lower part of the Kwla sequence, whereas the 800-ft sand aquifer is correlative with the upper sands of the Kw1a and Kw1b sequences (Sugarman and Miller, 1997).

At outcrop, the Brigantine and Shiloh Marl Members constitute the most extensive members of the Kirkwood Formation (Owens et al., 1988). However, sand facies generally dominate in outcrop (e.g., the Grenloch Sand), and it is difficult to differentiate among the members of the Kirkwood Formation as defined here.

This Brigantine Member is lower lower Miocene at the stratotype, where it is dated as 23.6-20.2 Ma using Sr isotopes (Fig. 5). At the stratotype, the member is equivalent to both the $\mathrm{Kw} 0$ and $\mathrm{Kw} 1 \mathrm{a}$ sequences (Fig. 5). Both the Kw1a and overlying Kw1b sequences are assigned to ECDZ 1 of Andrews (1988). Sugarman et al. (1993) have shown that the Kwla sequence is 20.3$22 \mathrm{Ma}$ at boreholes throughout the southern coastal plain (ACGS\#4, Lacey MUA, Berkeley MUA, Atsion, and Clayton). Planktonic foraminifers at the base of the Kw1a are assignable to lower Miocene Zone N5, based on the presence of Globigerinoides altiaperturus (Poore and Bybell, 1988). Preliminary magnetostratigraphic analyses assign the Kw1 sequence partim at ACGS\#4 to Chronozone C6r (Sugarman et al., 1993). 